\title{
Heterocyclic Chemistry
}

\section{2-[(1E,3E)-4-Arylbuta-1,3-dien-1-yl]-4H-chromen-4-ones as Dienes in Diels-Alder Reactions - Experimental and Computational Studies}

\author{
Hélio M. T. Albuquerque, ${ }^{[a]}$ Clementina M. M. Santos, $^{[a, b]}{ }^{[}$Carlos F. R. A. C. Lima, ${ }^{[a, c]}$

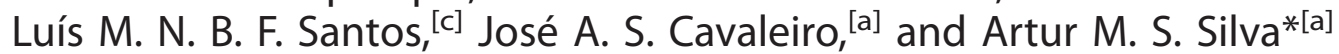

Abstract: The synthesis and reactivity of 2-[(1E,3E)-4-arylbuta1,3-dien-1-yl]-4H-chromen-4-ones as dienes in Diels-Alder (DA) reactions with several electron-poor and electron-rich dienophiles under microwave irradiation was studied. The optimized reaction conditions were achieved with $N$-methylmaleimide as the dienophile and $\mathrm{Sc}(\mathrm{OTf})_{3}(\mathrm{OTf}=$ triflate) as a Lewis acid under microwave-assisted and solvent-free conditions. The Lewis acid improved the reaction yields as it prevented the adducts obtained from undergoing a second DA reaction; thus, the for- mation of a bisadduct was avoided. The $\alpha, \beta: \gamma, \delta$-diene of the starting chromones was the most reactive, and the computational results confirmed the experimental findings. Theoretical calculations also provided a rationale for the unexpected lack of reactivity shown by some dienophiles. The adducts prepared were dehydrogenated with 2,3-dichloro-5,6-dicyano-1,4-benzoquinone (DDQ); however, the aza adducts were sensitive to the highly energetic reaction conditions necessary for the aromatization.

\section{Introduction}

Chromones (or 4H-chromen-4-ones) constitute a well-known class of naturally occurring oxygen-containing heterocycles. These compounds exhibit important biological properties such as anticancer, ${ }^{[1]}$ cytotoxic, $^{[2]}$ antioxidant, ${ }^{[1 b, 3]}$ anti-inflammatory, ${ }^{[4]}$ and antifungal ${ }^{[5]}$ activities. Their reactivities in several chemical transformations, namely, oxidations, thiations, hydrogenations, photolysis, condensations, dimerizations, and DielsAlder (DA) reactions have been reported widely. ${ }^{[6]}$ Since its discovery in 1928, the DA reaction, including its hetero variant, has remained an active research field and is the key step in the synthesis of a large variety of organic compounds. ${ }^{[7]}$

The use of chromone derivatives as dienes was first reported in 1954 and involved the DA reaction of 2-styrylchromones with maleic anhydride, ${ }^{[8]}$ and later with $\mathrm{N}$-arylmaleimides ${ }^{[9]}$ to afford the corresponding 1,2,3,9a-tetrahydroxanthone adducts. However, in 1992, Letcher and Yue revised the structure of the obtained adducts to the isomeric 1,2,3,4-tetrahydroxanthones on the basis of extensive NMR and IR spectroscopy studies. ${ }^{[10]}$ Years later, Kelkar et al. reported the use of 2-vinylchromones in [4+2] cycloaddition reactions with electron-rich enamine di-

[a] Department of Chemistry \& QOPNA, University of Aveiro,

Campus de Santiago, 3810-193 Aveiro, Portugal

E-mail: artur.silva@ua.pt

https://sites.google.com/site/artursilvaua/silva-ams

[b] School of Agriculture, Polytechnic Institute of Bragança, Campus de Santa Apolónia, 5300-253 Bragança, Portugal

[c] CIQ-UP, Department of Chemistry and Biochemistry, Faculty of Sciences, University of Porto,

Porto, Portugal

(iD) Supporting information and $O R C I D(s)$ from the author(s) for this article are available on the WWW under http://dx.doi.org/10.1002/ejoc.201601072. enophiles to provide several xanthone-type compounds. ${ }^{[11]}$ Recently, the reactivity of (E)-2-(4-arylbut-1-en-3-yn-1-yl)chromones in DA reactions with $\mathrm{N}$-methylmaleimide (NMM) as the dienophile was used for the synthesis of xanthone-1,2,3-triazole dyads. ${ }^{[12]}$ The diene system of (E)-2-(4-arylbut-1-en-3-yn-1yl)chromones was unreactive under classical heating conditions; however, the DA reaction under microwave (MW) irradiation afforded the expected 1,2,3,4-tetrahydroxanthone structure, which was further transformed to the aforementioned dyads. Meanwhile, our research group also tested the reactivity of 3-styrylchromones as dienes in [4+2] cycloaddition reactions with electron-poor dienophiles. Once again, the respective adducts were obtained in better yields through a MV-assisted protocol than through classical heating conditions. Owing to the advantages provided by the use of MV irradiation in DA reactions, experimental and computational studies on the MV-assisted DA reactions of 2-[(1E,3E)-4-arylbuta-1,3-dien-1-yl]-4Hchromen-4-ones with several electron-poor and electron-rich dienophiles are disclosed herein. On the basis of the reactivity of each diene system of the starting chromones, we expected to synthesize styryl-substituted xanthones (through the DA reaction of the $3,2: \alpha, \beta$-diene) or aryl-substituted flavones (through the DA reaction of the $\alpha, \beta: \gamma, \delta$-diene), but the results indicate that only flavone-type compounds are formed (Figure 1).

Xanthone and flavone derivatives both have unquestionable biological benefits, as supported by several reports of their use as anticancer, antioxidant, and anti-inflammatory agents, among others. ${ }^{[13]}$ Although the activities of simple xanthone ${ }^{[14]}$ or flavone ${ }^{[15]}$ scaffolds addresses only one biological target, there is a general belief that agents that modulate more than one target could have improved efficiencies compared with 


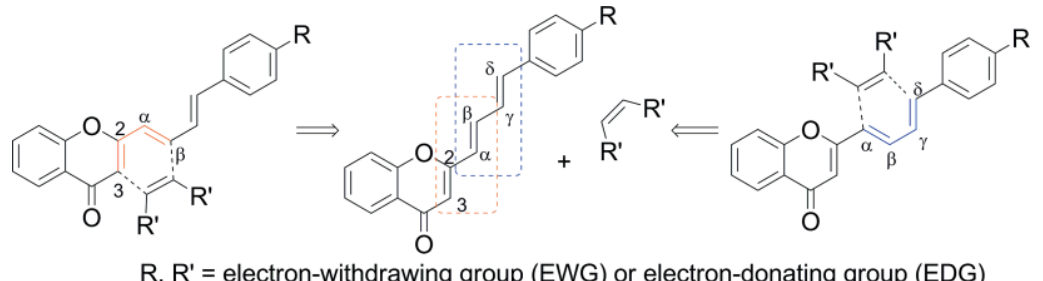

$\mathrm{R}, \mathrm{R}^{\prime}=$ electron-withdrawing group $(\mathrm{EWG})$ or electron-donating group (EDG)

Figure 1. Two possible sites for DA reactions in 2-[(1E,3E)-4-arylbuta-1,3-dien-1-yl]-4H-chromen-4-ones. $\mathrm{R}, \mathrm{R}^{\prime}=\mathrm{electron-withdrawing}$ group (EWG) or electrondonating group (EDG).

those of single-target drugs for complex multifactorial diseases such as cancer or Alzheimer's disease. ${ }^{[16]}$ In the present work, $\mathrm{N}$-methyl- and $\mathrm{N}$-phenylmaleimides were used as dienophiles to provide dyads bearing the isoindoline-1,3-dione unit, which is an interesting scaffold that has already been studied in a multitarget approach for the treatment of cancer ${ }^{[17]}$ and Alzheimer's disease. ${ }^{[18]}$ Thus, it is expected that the new hybrid structures may have greater biological relevance in the multitarget-drug research field than the simpler xanthone and flavone derivatives.

\section{Results and Discussion}

\section{DA Reactions of 2-[(1E,3E)-4-Arylbuta-1,3-dien-1-yl]-4H- chromen-4-ones}

2-[(1E,3E)-4-Arylbuta-1,3-dien-1-yl]-4H-chromen-4-ones (3a-3e) were prepared in good yields (68-80\%) through the base-catalyzed aldol condensation of 2-methyl-4H-chromen-4-one (1) with the appropriate cinnamaldehyde $\mathbf{2 a}-\mathbf{2 e}$ according to a previously reported methodology (Scheme 1). ${ }^{[19]}$ 2-Methyl-4Hchromen-4-one was prepared through a previously reported three-step Baker-Venkataraman sequence in good overall yield, ${ }^{[14 c]}$ whereas the cinnamaldehydes $\mathbf{2} \mathbf{b}-\mathbf{2} \mathbf{d}$, which are not commercially available, were obtained through palladium-catalyzed cross-coupling reactions of aryl iodides with acrolein diethyl acetal. ${ }^{[20]}$

On the basis of our previous results on the MV-assisted DA reactions of 2-[(1E)-4-arylbut-1-en-3-yn-1-yl]chromones, ${ }^{[12]}$ we initially attempted the DA reaction of chromone $3 c$ with in- creasing amounts of NMM in dry $\mathrm{N}, \mathrm{N}$-dimethylformamide (DMF) for $40 \mathrm{~min}$ at $160^{\circ} \mathrm{C}$ under multimode MV irradiation (Table 1, Entries 1-3). Adduct 5c (NMR data in Supporting Information) was isolated as the major product in $30-31 \%$ yield (Table 1, Entries 1-3). The DA reaction occurred at the $\alpha, \beta: \gamma, \delta$-diene, and the structure of adduct $\mathbf{5 c}$ arises from the olefin migration of the expected DA cycloadduct 4c, which was also isolated (Table 1, Entry 10). The bisadduct 7c was isolated as a mixture of four diastereomers (two major diastereomers and traces of the other two) when a large excess of NMM was employed (Table 1, Entries 6-9). Its formation should involve a cascade of four reactions: the DA reaction at the $\alpha, \beta: \gamma, \delta$-diene gives intermediate $\mathbf{4 c}$ and subsequent olefin migration affords adduct $\mathbf{5 c}$, the diene of which undergoes a new DA reaction to yield an intermediate structure that provides bisadduct 7c upon olefin migration (Scheme 2). The formation of bisadduct 7c was further confirmed by the reaction of the isolated adduct $\mathbf{5 c}$ with NMM under in solvent-free conditions with monomode MV irradiation (Table 3). The two major diastereomers found in a 52:48 \% mixture were assigned as structures I and II (Scheme 3), and we were able to isolate the former one in a pure form and fully characterize it (NMR data in Supporting Information). The stereochemistry of diastereomer I of bisadduct 7c was assessed through the observed NOE cross-peaks of (1) H-14c with $\mathrm{H}-14 \mathrm{~b}$ and $\mathrm{H}-3 \mathrm{a}$; (2) $\mathrm{H}-4$ with $\mathrm{H}-3 \mathrm{a}$ and $\mathrm{H}-5$, which indicate the formation of the endo product from the first DA reaction; and (3) $\mathrm{H}$ $5 \mathrm{~b}$ with $\mathrm{H}-5 \mathrm{a}$ and $\mathrm{H}-8 \mathrm{a}$ as well as the absence of close proximity between $\mathrm{H}-5 \mathrm{a}$ with $\mathrm{H}-14 \mathrm{~b}$, which suggests that the second DA reaction also afforded an endo adduct. However, the second addition can occur at the same face as the first one to yield the endo/endo(cis) adduct or at the opposite face to afford the endo/endo(trans) adduct (Scheme 3). Then, each one of these

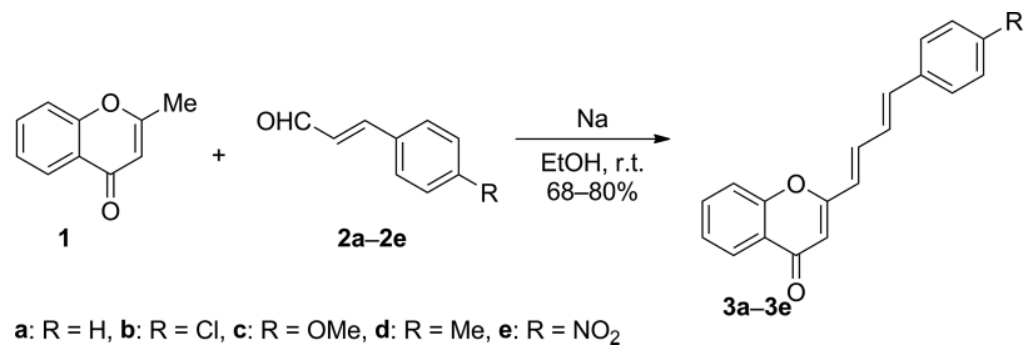

Scheme 1. Synthesis of chromones $\mathbf{3 a} \mathbf{a} \mathbf{- 3 e}$ used as dienes in DA reactions. 
diastereomers undergoes olefin migration to provide two diastereomers. In the NOESY spectrum of a mixture enriched in diastereomer II of bisadduct 7c, one can deduce the close proximity of $\mathrm{H}-5$ a with $\mathrm{H}-5 \mathrm{~b}$ and $\mathrm{H}-14 \mathrm{~b}$ as well as $\mathrm{H}-5 \mathrm{~b}$ with $\mathrm{H}-8 \mathrm{a}$, which confirms the endo/endo(cis) diastereomer (Scheme 3). In the spectrum of the crude reaction mixture, we observed the typical signals of the diastereomers I and II as well as other small ones corresponding to the $\mathrm{H}-8 \mathrm{a}, \mathrm{OMe}$, and $\mathrm{N}$-Me signals of another two compounds, which were assigned to diastereomers III and IV (trace amounts). The variation of the tempera- ture, reaction time, or dienophile amount did not improve the yields of adduct $\mathbf{5 c}$ or bisadduct 7c (Table 1, Entries 4-10). Interestingly, if the reaction was performed for $10 \mathrm{~min}$, adduct $\mathbf{6 c}$ (NMR data in Supporting Information) was isolated in $6 \%$ yield (Table 1, Entry 5). In this case, the DA reaction occurred at the $3,2: \alpha, \beta$-diene to give a styryl-substituted tetrahydroxanthene structure. By performing the reaction at $130{ }^{\circ} \mathrm{C}$, it was possible to isolate derivative $\mathbf{4 c}$ in $8 \%$ yield (Table 1, Entry 10). This confirms that the more stable adduct $\mathbf{5 c}$ results from the olefin migration of the expected DA cycloadduct 4c (NMR data in

Table 1. Optimization of the DA reaction of chromone $3 \mathrm{c}$ with NMM under multimode MW irradiation. The reactions were performed in dry DMF (10 $\mu \mathrm{L}$ ).

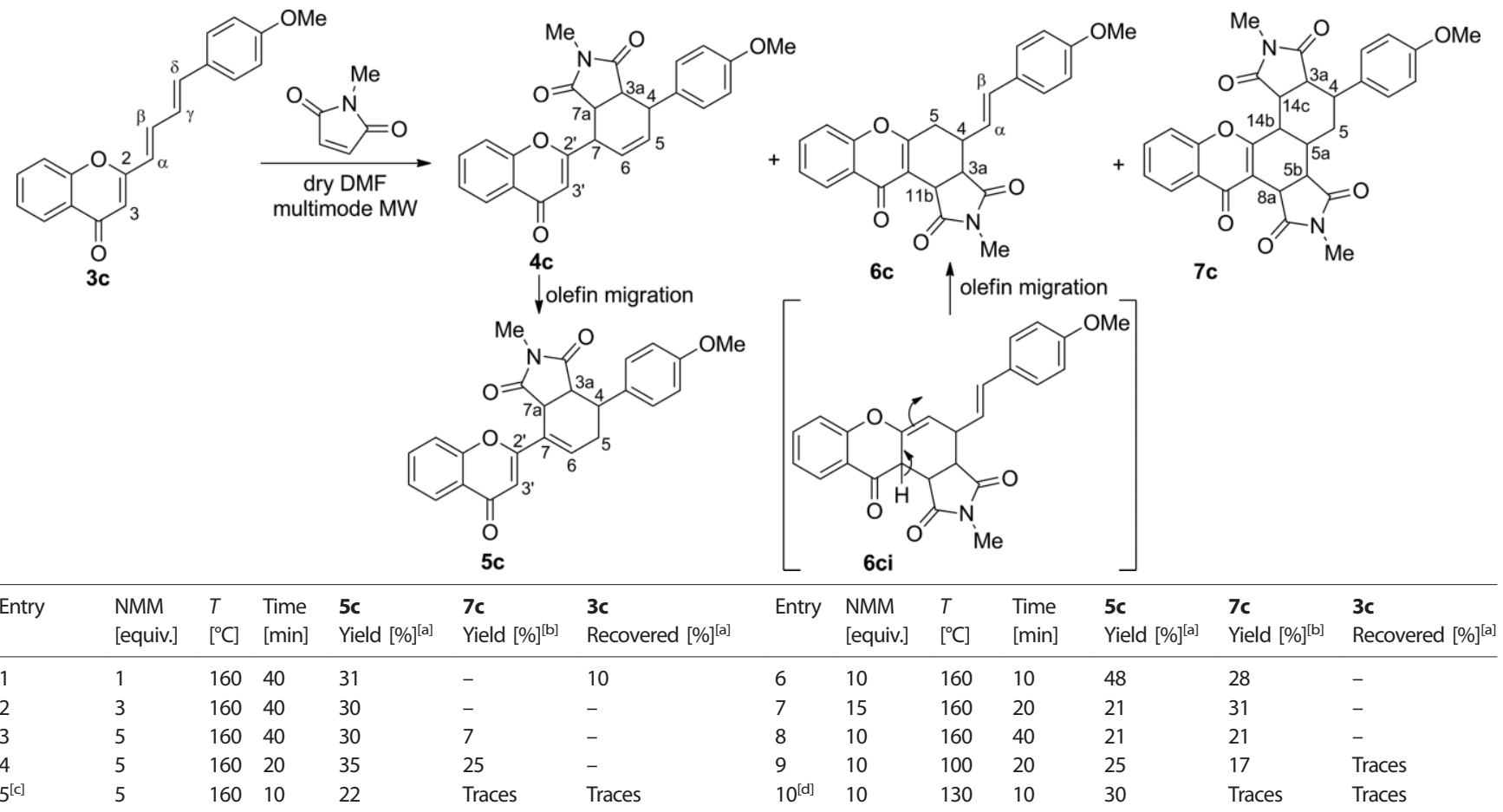

[a] Isolated yields. [b] Isolated yield of a mixture of diastereomers. [c] Derivative $\mathbf{6 c}$ isolated in $6 \%$ yield. [d] Derivative $\mathbf{4 c}$ isolated in $8 \%$ yield.

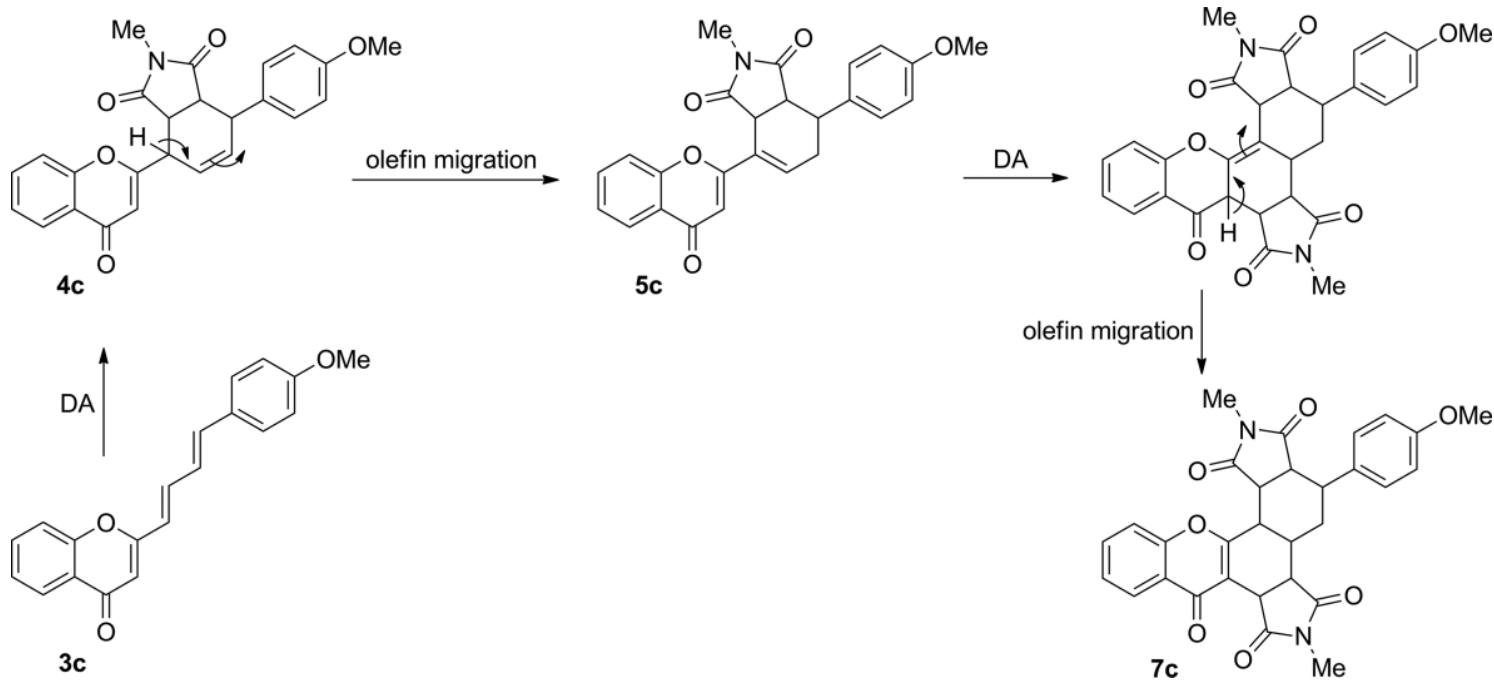

Scheme 2. Tandem DA/olefin migration processes to form bisadduct 7c. 

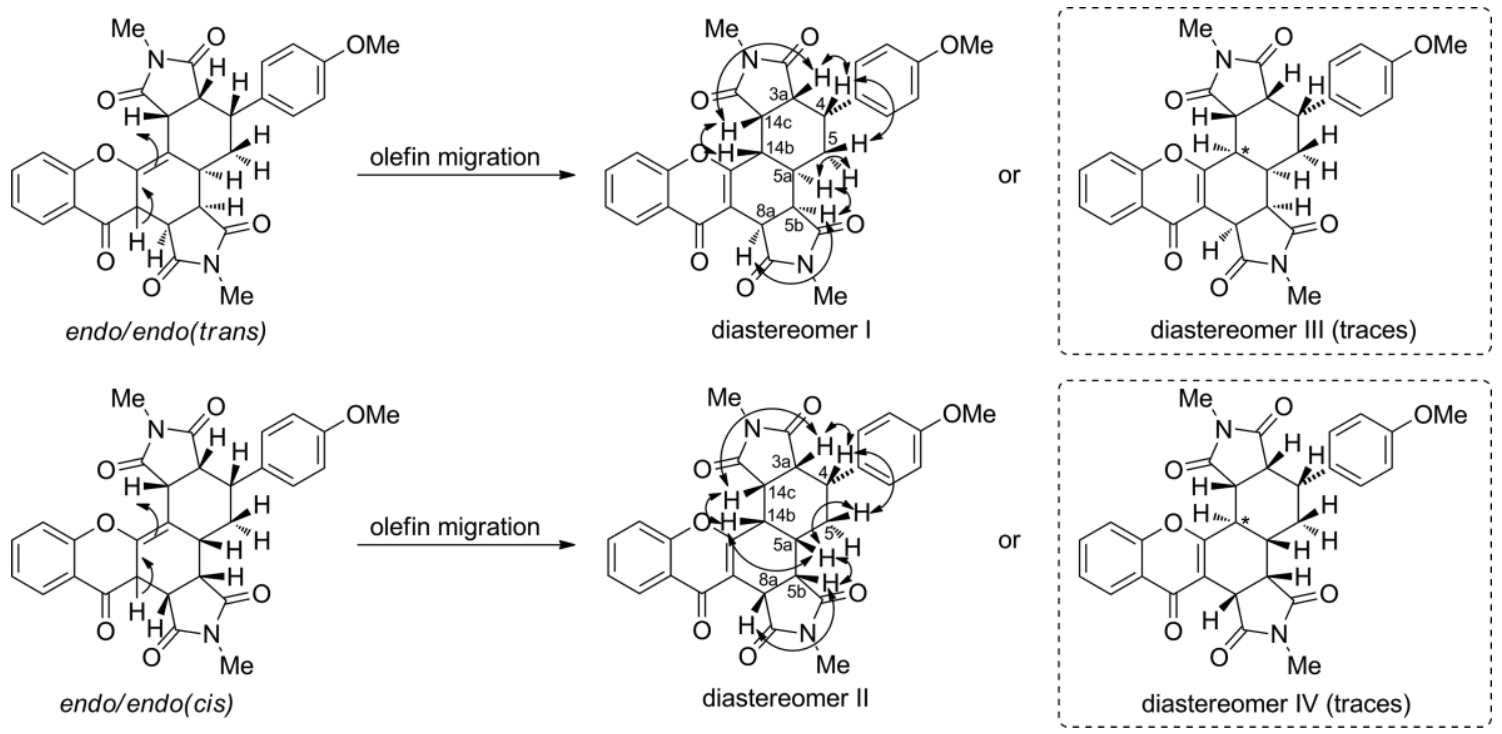

Scheme 3. Stereochemistry (NOESY) of the olefin migration of $\mathbf{7 c}$ endo/endo(trans) and endo/endo(cis) products.

Supporting Information). Our aforementioned preliminary experimental results strongly suggest that the $\alpha, \beta: \gamma, \delta$-diene system is the most reactive or at least affords the more thermodynamically stable DA product. To obtain more insights into this DA reaction, we evaluated its thermodynamic feasibility by computational methods at the M06-2X/6-31+G(d,p) level of theory (detailed results are presented in Table S1). We started with the conformational analysis of the reactants $\mathbf{3 a}, \mathbf{3} \mathbf{c}, \mathbf{3 d}$, and $\mathbf{3 e}$, as only the cis double bonds are reactive towards the DA reaction.

The results indicate that the all-trans reactant is the major species with a molar fraction of around 0.89 at $T=160{ }^{\circ} \mathrm{C}$ (the temperature at which most reactions were performed). The species with all cis double bonds has a molar fraction of less than 0.01 and can in principle be ignored. The two reactive conformers cis-3,2: $\alpha, \beta$-diene (which yields 6 upon DA reaction) and cis$\alpha, \beta: \gamma, \delta$-diene (which yields 4 ) are present in small amounts of ca. 0.08 and 0.02 , respectively. However, as the conversion between these isomers is rather fast at high temperatures, these quantities should suffice for the respective DA reactions to proceed smoothly. ${ }^{[21]}$ The influence of the substituent R group (Figure 1) in the conformational distribution was found to be negligible. The calculated energy levels of the highest occupied molecular orbital and the lowest unoccupied molecular orbital (HOMO/LUMO) confirm the kinetic viability of the direct DA reaction through comparison with the calculated HOMO and LUMO of the NMM dienophile (Table S4, Supporting Information) and also vary very little with the substituent $R$.

These results suggest that the influence of the $R$ group on the intrinsic thermodynamic and kinetic DA reactivity of $\mathbf{3}$ is of minor importance, as is consistent with the rather large distance of the substituent from the reactive diene centers. Hence, to speed up the calculations, only $\mathbf{3 a}(\mathrm{R}=\mathrm{H})$ was considered for the subsequent computational studies. We also evaluated each possible reaction of $\mathbf{3} \mathbf{a}$ with NMM separately to yield the four possible products $(\mathbf{4} \mathbf{a}, \mathbf{5} \mathbf{a}, \mathbf{6} \mathbf{a}$, and $\mathbf{7 a}$ ) presented in Table 1 .
As $\mathbf{4 a} \mathbf{a} \mathbf{5} \mathbf{a}$, and $\mathbf{6} \mathbf{a}$ are isomers, the direct comparison between their energies gives information about which reaction pathway is thermodynamically preferred (Table S2, Supporting Information). The optimized structures of $\mathbf{4 a}, \mathbf{5 a}, \mathbf{6} \mathbf{a}$, and $\mathbf{7 a}$ are presented in Table S5 (Supporting Information); various possible stable conformations were found for these compounds, but only the minimum energy configurations were considered. The energetic analysis indicates that the stabilities of $\mathbf{5} \mathbf{a}$ and $\mathbf{6} \mathbf{a}$ are very similar, $\Delta H_{298 \mathrm{~K}}(\mathbf{5 a} \rightarrow \mathbf{6 a}) \approx 0 \mathrm{~kJ} \mathrm{~mol}^{-1}\left(H_{298 \mathrm{~K}}\right.$ is the calculated enthalpy at $T=298.15 \mathrm{~K})$. However, the energy difference between their precursors, $\mathbf{4 a}$ and $\mathbf{6} \mathbf{a}_{\mathbf{i}}$, respectively, which are formed through the initial DA reaction and before the olefin migration, is much more substantial, $\Delta H_{298 \mathrm{~K}}\left(\mathbf{4 a} \rightarrow \mathbf{6} \mathbf{a}_{\mathrm{i}}\right) \approx$ $29 \mathrm{~kJ} \mathrm{~mol}^{-1}$. The $\Delta H_{298 \mathrm{~K}}$ values for the olefin migrations were calculated as $-27 \mathrm{~kJ} \mathrm{~mol}^{-1}$ for $\mathbf{4 a} \rightarrow \mathbf{5 a}$ and $-57 \mathrm{~kJ} \mathrm{~mol}^{-1}$ for $\mathbf{6} \mathbf{a}_{\mathbf{i}} \rightarrow \mathbf{6} \mathbf{a}$. The computational results also indicate that the DA reactions with NMM $(\mathbf{3} \rightarrow \mathbf{4}, \mathbf{3} \rightarrow \mathbf{6}, \mathbf{5} \rightarrow \mathbf{7})$ are significantly favored energetically, and the calculated $\Delta_{\mathrm{r}} H_{298 \mathrm{~K}}$ values are in the order of -120 to $-150 \mathrm{~kJ} \mathrm{~mol}^{-1}$. To better visualize these results, the calculated relative enthalpy $(T=298.15 \mathrm{~K}$ ) versus reaction coordinate diagram is shown in Figure 2 for the DA reaction of 3a with NMM (to yield the two intermediates $\mathbf{4 a}$ and $\mathbf{6 a i}$ ) and subsequent olefin migration (to form $\mathbf{5} \mathbf{a}$ and $\mathbf{6} \mathbf{a}$, respectively).

These results support the experimental findings by indicating that (1) 6 should be a minor product of the DA reaction, (2) the preferred pathway for product 7 should be a second DA reaction of $\mathbf{5}$, and (3) the olefin migration of the DA adducts should be thermodynamically spontaneous.

To improve the yields of adducts $\mathbf{5}$, the reaction was performed under solvent-free conditions with monomode MV irradiation. Thus, the DA reaction of chromone $3 c$ with NMM was performed with the variation of the amount of dienophile and the reaction time (Table 2, Entries 1-5). The best yield for adduct $\mathbf{5 c}(47 \%)$ was obtained in 10 min with 2 equiv. of NMM, and $5 \%$ of the starting chromone $3 \mathbf{c}$ was recovered (Table 2, Entry 3). The reactions at 130 and $100{ }^{\circ} \mathrm{C}$ with 2 equiv. of NMM 


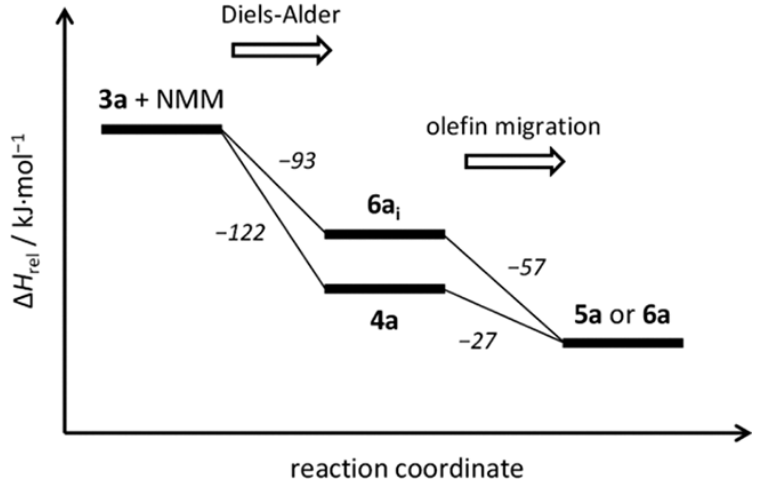

Figure 2. Enthalpy (at $T=298.15 \mathrm{~K}$ ) versus reaction coordinate diagram for the DA reaction of 3a with NMM, calculated at the M06-2X/6-31+G(d,p) level of theory.

for 15 min (Table 2, Entries 6 and 7) afforded less byproduct, and the yield of adduct $\mathbf{5 c}$ was higher at $130{ }^{\circ} \mathrm{C}$, at which $37 \%$ of the starting chromone $3 \mathrm{c}$ was recovered. Owing to the moderate yields of adduct $\mathbf{5 c}$, the influence of the Lewis acid was assessed. If a stoichiometric amount of $\mathrm{AlCl}_{3}$ was employed at different temperatures, adduct $\mathbf{5 c}$ was obtained in low yields (27-29\%), and $45-57 \%$ of the starting chromone $3 \mathrm{c}$ was recovered (Table 2, Entries 8 and 9). If the Lewis acid was changed to $\mathrm{Sc}(\mathrm{OTf})_{3}(\mathrm{OTf}=$ triflate $)$ and the amount of dienophile was varied, the yield of adduct $\mathbf{5 c}$ increased to $62-67 \%$, and the best yield was achieved with 3 or 4 equiv. of NMM (Table 2, Entries 10-12). A single reaction was attempted with $30 \mathrm{~mol}-\%$ of $\mathrm{Sc}(\mathrm{OTf})_{3}$ for $10 \mathrm{~min}$ at $165^{\circ} \mathrm{C}$ (Table 2, Entry 13), but, unfortunately, the yield of adduct $\mathbf{5 c}$ decreased to $37 \%$; this result implies that the effect of $\mathrm{Sc}(\mathrm{OTf})_{3}$ is stoichiometric rather than catalytic. In our particular case, the Lewis acid can complex with the carbonyl groups of NMM or with the carbonyl group of chromone $\mathbf{3 c}$. The chelation with NMM makes this dienophile more electron-poor and, as a consequence, the DA reaction is favored with an electron-rich diene. Furthermore, the chelation of the Lewis acid with the carbonyl group of chromone $\mathbf{3 c}$ makes the 3,2: $\alpha, \beta$-diene more electron-poor, and the DA reaction at this site is disfavored (Figure $3 \mathrm{~A}$ ). The chelation with the carbonyl group of adduct $\mathbf{5 c}$ also makes the newly formed diene more electron-poor; once again, the DA reaction is disfavored and, consequently, the yield of bisadduct $\mathbf{7 c}$ decreases (Figure 3B).

To reinforce this idea, DA reactions of adduct $\mathbf{5 c}$ with an excess of NMM in the presence or absence of $\mathrm{Sc}(\mathrm{OTf})_{3}$ were performed (Table 3, Entries 1-3). Both DA reactions performed in the absence of $\mathrm{Sc}(\mathrm{OTf})_{3}$ afforded bisadduct $7 \mathrm{c}$ as a mixture of diastereomers in 48 and $60 \%$ yield with $20-37 \%$ of the starting adduct $\mathbf{5 c}$ recovered (Table 3, Entries 1 and 2). For the reaction in the presence of a stoichiometric amount of $\mathrm{Sc}(\mathrm{OTf})_{3}$, bisad-

Table 2. The optimization of the DA reaction of chromones 3a-3e with NMM under solvent-free conditions with monomode MW irradiation.<smiles>[R]c1ccc(/C=C/C=C/c2cc(=O)c3ccccc3o2)cc1</smiles>

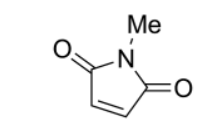

solvent-free monomode MW

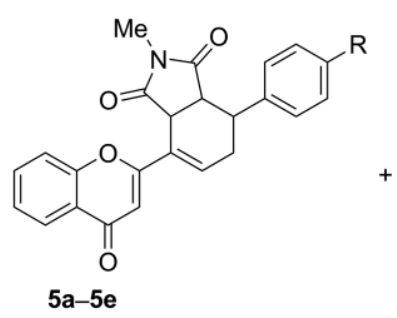

$5 a-5 e$<smiles>COc1ccc(C2CC3C4C(=O)N(C)C(=O)C4c4oc5ccccc5c(=O)c4C3C3C(=O)N(C)C(=O)C23)cc1</smiles>

7c

a: $\mathrm{R}=\mathrm{H}, \mathbf{b}: \mathrm{R}=\mathrm{Cl}, \mathbf{c}: \mathrm{R}=\mathrm{OMe}, \mathbf{d}: \mathrm{R}=\mathrm{Me}, \mathbf{e}: \mathrm{R}=\mathrm{NO}_{2}$

\begin{tabular}{|c|c|c|c|c|c|c|c|}
\hline Entry & Derivative & $\begin{array}{l}\text { NMM } \\
\text { [equiv.] }\end{array}$ & $\begin{array}{l}T \\
{\left[{ }^{\circ} \mathrm{C}\right]}\end{array}$ & $\begin{array}{l}\text { Time } \\
\text { [min] }\end{array}$ & Lewis acid & $\begin{array}{l}\mathbf{5} \\
\text { Yield [\%] }]^{[a]}\end{array}$ & $\begin{array}{l}\mathbf{3} \\
\text { Recovered [\%] }]^{[a]}\end{array}$ \\
\hline 1 & $3 c$ & 1 & 165 & 15 & - & 37 & 33 \\
\hline 2 & $3 c$ & 2 & 165 & 15 & - & 44 & - \\
\hline 3 & $3 c$ & 2 & 165 & 10 & - & 47 & 5 \\
\hline 4 & $3 c$ & 2 & 165 & 5 & - & 45 & 26 \\
\hline $5^{[b]}$ & $3 c$ & 5 & 165 & 15 & - & 25 & - \\
\hline 6 & $3 c$ & 2 & 130 & 15 & - & 40 & 37 \\
\hline 7 & $3 c$ & 2 & 100 & 15 & - & 20 & 66 \\
\hline $8^{[\mathrm{c}]}$ & $3 c$ & 2 & 165 & 10 & $\mathrm{AlCl}_{3}$ & 29 & 45 \\
\hline $9^{[c]}$ & $3 c$ & 2 & 130 & 15 & $\mathrm{AlCl}_{3}$ & 27 & 57 \\
\hline $10^{[c]}$ & $3 c$ & 2 & 165 & 10 & $\mathrm{Sc}(\mathrm{OTf})_{3}$ & 62 & 21 \\
\hline $11^{[c]}$ & $3 c$ & 3 & 165 & 10 & $\mathrm{Sc}(\mathrm{OTf})_{3}$ & 67 & 5 \\
\hline $12^{[c]}$ & $3 c$ & 4 & 165 & 10 & $\mathrm{Sc}(\mathrm{OTf})_{3}$ & 67 & 8 \\
\hline $13^{[d]}$ & $3 c$ & 3 & 165 & 10 & $\mathrm{Sc}(\mathrm{OTf})_{3}$ & 37 & - \\
\hline $14^{[c]}$ & $3 c$ & 2 & 165 & 15 & $\mathrm{Sc}(\mathrm{OTf})_{3}$ & 59 & 26 \\
\hline $15^{[\mathrm{cc}]}$ & $3 c$ & 2 & 130 & 15 & $\mathrm{Sc}(\mathrm{OTf})_{3}$ & 47 & 17 \\
\hline $16^{[c]}$ & $3 a$ & 3 & 165 & 10 & $\mathrm{Sc}(\mathrm{OTf})_{3}$ & 77 & - \\
\hline $17^{[c]}$ & 3b & 3 & 165 & 10 & $\mathrm{Sc}(\mathrm{OTf})_{3}$ & 55 & 14 \\
\hline $18^{[\mathrm{c}]}$ & 3d & 3 & 165 & 10 & $\mathrm{Sc}(\mathrm{OTf})_{3}$ & 71 & - \\
\hline $19^{[c]}$ & $3 e$ & 3 & 165 & 10 & $\mathrm{Sc}(\mathrm{OTf})_{3}$ & 52 & 25 \\
\hline
\end{tabular}

[a] Isolated yield. [b] $25 \%$ of bisadduct 7c was isolated. [c] 100 mol-\% of Lewis acid. [d] 30 mol-\% of Lewis acid. 


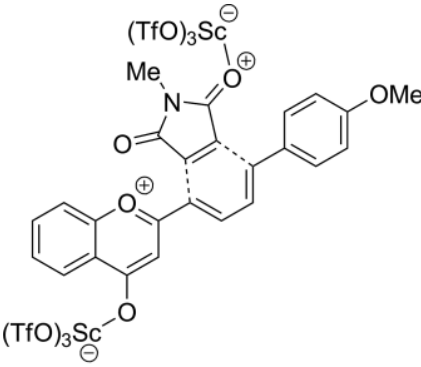

A - Favored DA reaction<smiles></smiles>

B - Unfavored DA reaction

Figure 3. Effect of Lewis acid on the DA reaction: (A) chelation with chromone 3c and NMM, (B) chelation with adduct 5c and $\mathrm{N}$-methylmaleimide.

duct 7c was obtained as a mixture of diastereomers in only $15 \%$ yield, and $75 \%$ of $\mathbf{5 c}$ was recovered (Table 3, Entry 3). These results confirm our suspicions that the Lewis acid chelation makes the 3,2: $\alpha, \beta$-diene more electron-poor and directs the DA reaction towards $\mathbf{5 c}$.

Table 3. DA reaction of $\mathbf{5 c}$ with NMM in the presence or absence of $\mathrm{Sc}(\mathrm{OTf})_{3}$. Reactions performed with 6 equiv. of NMM.

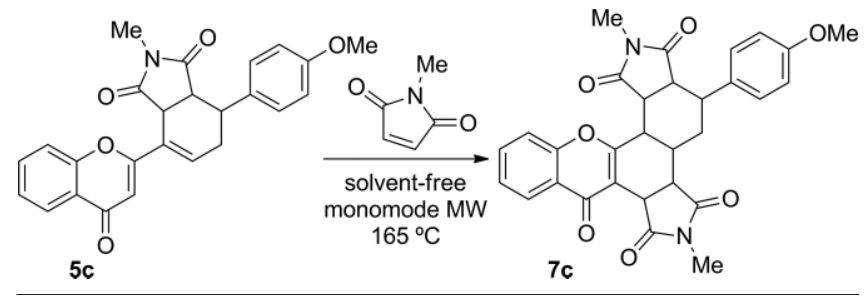

\begin{tabular}{lllll}
\hline Entry & $\begin{array}{l}\text { Time } \\
{[\mathrm{min}]}\end{array}$ & Lewis acid & $\begin{array}{l}\mathbf{7 c} \\
\text { Yield [\%] }{ }^{[a]}\end{array}$ & $\begin{array}{l}\mathbf{5 c} \\
\text { Recovered }[\%]^{[b]}\end{array}$ \\
\hline 1 & 20 & - & 48 & 37 \\
2 & 30 & - & 60 & 20 \\
$3^{[c]}$ & 20 & Sc(OTf) & 15 & 75 \\
\hline
\end{tabular}

[a] Isolated yield of a mixture of diastereomers. [b] Isolated yield. [c] $100 \mathrm{~mol}-$ $\%$ of Lewis acid.

The best reaction conditions for adduct 5c were achieved with 3 equiv. of NMM in the presence of 1 equiv. of $\mathrm{Sc}(\mathrm{OTf})_{3}$ for $10 \mathrm{~min}$ at $165{ }^{\circ} \mathrm{C}$ (Table 2, Entry 11). The same conditions were applied to chromones $\mathbf{3 a}, \mathbf{3 b}, \mathbf{3 d}$, and $\mathbf{3 e}$ (Table 2, Entries 16-19), and the corresponding adducts $\mathbf{5 a}, \mathbf{5 b}, \mathbf{5 d}$, and $\mathbf{5 e}$ were obtained in moderate-to-good yields (52-77\%). To confirm our previous suggestion for the formation of the endo adduct 5, a NOESY experiment was performed on adduct 5e to address the stereochemistry of the reaction. The NOE crosspeaks showed the close proximity of $\mathrm{H}-3 \mathrm{a}$ with $\mathrm{H}-4$ and $\mathrm{H}-7 \mathrm{a}$; therefore, the adducts 5 are endo products (Figure 4).

The effect of Lewis acid chelation was further evaluated by computational chemistry at the M06-2X/6-31+G(d,p) level of theory (the detailed results are presented in the Supporting Information). The results indicate that $\mathrm{Sc}(\mathrm{OTf})_{3}$ will bind preferentially to the $\mathrm{C}=\mathrm{O}$ group of the chromone ring, and chelation with other groups or atoms of the diene or the dienophile is of minor importance. Chelation with a Lewis acid seems not to alter significantly the shapes of the HOMOs and LUMOs of $\mathbf{3 a}$ and $\mathbf{5 a}$. However, the computational results suggest that chela-

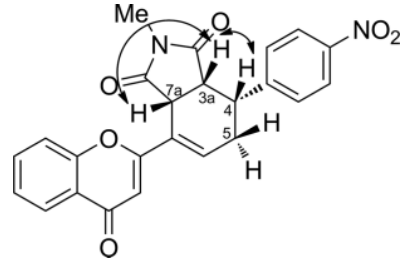

Figure 4. Most important NOE cross-peaks of adduct $\mathbf{5 e .}$

tion reduces the overall reactivity of the dienes towards the DA reaction because it (1) increases the HOMO/LUMO gap between the diene and dienophile (by decreasing the HOMO energy of the diene) and (2) decreases the double-bond character of the reactive chromone double bond and, thus, decreases the reactivity of the 3,2: $\alpha, \beta$-diene. Hence, on the basis of the experimental and computational findings, the most probable cause for the increased yield of product 5 in the presence of $\mathrm{Sc}(\mathrm{OTf})_{3}$ is that chelation reduces the reactivity of $\mathbf{5}$ towards the second DA reaction, which consumes it to afford bisadduct 7 .

With these results in hand, we turned our attention to the scope of dienophiles in DA reactions with chromone $3 \mathbf{c}$, as depicted in Table 4. N-Phenylmaleimide afforded adduct 8 in $66 \%$ yield (Table 4, Entry 1). The reactivities of dimethyl and diethyl acetylenedicarboxylate with chromone $\mathbf{3 c}$ were also tested, and the expected aromatic products $\mathbf{9 a}$ and $\mathbf{9 b}$ (NMR data in Supporting Information) were obtained in $30-45 \%$ yield (Table 4, Entries 2-4).

The dienophile scope was further extended to diethyl and diisopropyl azodicarboxylate (DEAD and DIAD, respectively; Table 4, Entries 5 and 6) to afford the expected adducts 10a and $\mathbf{1 0 b}$ in 22 and $57 \%$ yield, respectively. In the reaction with DEAD, derivative $\mathbf{1 1}$ was isolated in $22 \%$ yield as the product of an Alder-ene reaction of adduct 10a. The formation of this Alder-ene product 11 (NMR data in Supporting Information) can be explained on the basis of a tandem DA/Alder-ene process (Scheme 4). To avoid the formation of the Alder-ene product 11, the reaction was attempted at 80 and $100{ }^{\circ} \mathrm{C}$; however, no reaction products were observed. By performing the reaction at $130{ }^{\circ} \mathrm{C}$, cycloadduct $\mathbf{1 0 a}$ was isolated in trace amounts together with unreacted chromone $\mathbf{3 c}$ and derivative 11 in $30 \%$ yield. 4-Phenyl-1,2,4-triazoline-3,5-dione (PTAD) was expected to show similar or even improved reactivity compared with those of maleimides or azodicarboxylates. Unfortunately, no DA products were observed when the reaction was performed at different temperatures and in the presence or absence of DMF as solvent (Table 4, Entries 7-9). The reason for this may be that the high temperatures employed in DA reactions probably lead to the dimerization of PTAD, ${ }^{[22]}$ and this reaction competes with the DA reaction. Electron-poor dienophiles such as diethyl fumarate and maleate were extremely reluctant towards the DA reaction with chromone $\mathbf{3 c}$. Even at higher temperatures and longer reaction times, no DA reaction was observed. Instead, more degradation products and less recovered chromone were detected (Table 4, Entries 10-13). Reactions involving the electron-rich dienophile 3,4-dihydro- $2 \mathrm{H}$-pyran (Table 4, Entries 14 and 15) were attempted at different temperatures, but no DA reaction occurred. 
Table 4. Dienophile scope in the DA reactions of chromone $\mathbf{3 c}$ under monomode MW irradiation; the reactions were performed under solvent-free or neat conditions.

\begin{tabular}{|c|c|c|c|c|c|c|}
\hline Entry & Dienophile & $\begin{array}{c}T \\
{\left[{ }^{\circ} \mathrm{C}\right]}\end{array}$ & $\begin{array}{l}\text { Time } \\
\text { [min] }\end{array}$ & Product & $\begin{array}{l}\text { Yield } \\
{[\%]^{[a]}}\end{array}$ & $\begin{array}{c}\text { 3c } \\
\text { Recovered [\%] }]^{[a]}\end{array}$ \\
\hline $1^{[b]}$ & & 165 & 10 & & 66 & - \\
\hline 2 & & 130 & 15 & & 30 & 33 \\
\hline 3 & & 165 & 15 & & 35 & - \\
\hline 4 & $\mathrm{EtO}_{2} \mathrm{C}=\mathrm{CO}_{2} \mathrm{Et}$ & 165 & 15 & & 45 & - \\
\hline $5^{[e]}$ & $-\mathrm{CO}_{2} \mathrm{Et}$ & 165 & 15 & & 22 & - \\
\hline 6 & $\mathrm{PrO}_{2} \mathrm{C}_{-\mathrm{N}}=\mathrm{N}_{-\mathrm{CO}_{2} \mathrm{iPr}}$ & 165 & 10 & & 57 & - \\
\hline 7 & $\mathrm{Ph}$ & 165 & 10 & [d] & - & 63 \\
\hline $8^{[\mathrm{cc}]}$ & & 130 & 10 & [d] & - & 40 \\
\hline $9^{[c]}$ & & 165 & 10 & [d] & - & - \\
\hline $\begin{array}{l}10 \\
11\end{array}$ & $\mathrm{EtO}_{2} \mathrm{C}$ & $\begin{array}{l}130 \\
165\end{array}$ & $\begin{array}{l}10 \\
10\end{array}$ & $\begin{array}{l}\text { no reaction } \\
\text { no reaction }\end{array}$ & $\overline{-}$ & $\begin{array}{l}90 \\
90\end{array}$ \\
\hline $\begin{array}{l}11 \\
13 \\
\end{array}$ & $\mathrm{EtO}_{2} \mathrm{C}$ & $\begin{array}{l}165 \\
200\end{array}$ & $\begin{array}{l}40 \\
40\end{array}$ & $\begin{array}{l}\text { [d] } \\
{[\text { [d] }}\end{array}$ & - & $\begin{array}{l}60 \\
50\end{array}$ \\
\hline 14 & & 100 & 15 & no reaction & - & 90 \\
\hline 15 & & 165 & 15 & no reaction & - & 90 \\
\hline
\end{tabular}

[a] Isolated yield. [b] Addition of $100 \mathrm{~mol}-\%$ of Sc(OTf $)_{3}$. [c] DMF $(0.1 \mathrm{~mL})$ as solvent. [d] Unidentified byproducts. [e] The reaction with DEAD afforded the expected DA cycloadduct and the other product from the tandem DA/Alder-ene process.

In general, the relative reactivity of the dienophiles is indicated accurately by the calculated HOMO(diene)/LUMO(dienophile) energy differences, and there is some tendency for higher yields to be observed for lower HOMO/LUMO energy gaps. For instance, the highest HOMO/LUMO gap was observed for the dienophile in Table 4, Entries 14 and 15, the low reactivity of which may explain why no DA reaction occurred. The HOMO/ LUMO energies were calculated at the M06-2X/6-31+G(d,p) and $M P 2 / 6-31+G(d, p)$ levels of theory. The detailed results are presented in Table S4 (Supporting Information), and both methods predict similar tendencies in the HOMO/LUMO energies. How- ever, there are some cases that deviate from this analysis. In Table 4, Entries 7-9 and 12-13, although the calculated HOMO/ LUMO gaps are slightly higher than those for the most reactive dienophiles, the absence of DA reaction may mostly be due to the extensive decomposition of the dienophile in the reaction medium. For Table 4, Entries 10 and 11, the failure of the DA reaction is harder to explain; the HOMO/LUMO gap is comparable to those of the most reactive dienophiles, no unidentified byproducts were detected, and most of the unreacted reagent was recovered. Therefore, we turned our attention to the corresponding DA product analogous to $\mathbf{5}$. 
<smiles>COc1ccc(/C=C/C=C/c2cc(=O)c3ccccc3o2)cc1</smiles>

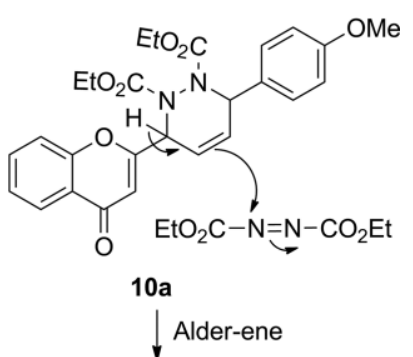

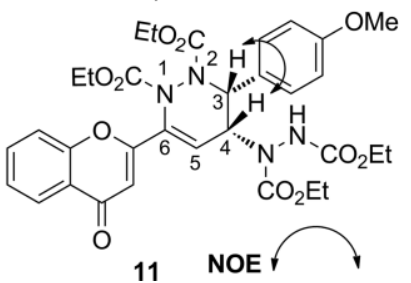

Scheme 4. Tandem DA/Alder-ene process to form 11.

The optimized geometry of this product (presented in Table S5, Supporting Information) evidences the existence of significant steric repulsion between the ester groups and the chromone and phenyl rings. This increases the calculated $\Delta_{\mathrm{r}} \mathrm{H}_{298 \mathrm{~K}}$ for the DA reaction between $\mathbf{3 a}$ and diethyl fumarate to yield the product analogous to $5 \mathrm{a}$ by ca. 10 and $40 \mathrm{~kJ} \mathrm{~mol}^{-1}$ relative to the reaction $\mathbf{3 a}+\mathrm{NMM} \rightarrow \mathbf{5 a}$ and the analogous reactions involving the similar dienophiles used in Table 4, Entries 5 and 6, respectively (Table S3, Supporting Information). In these last cases, the geometries of the $\mathrm{N}$ atoms in the DA products avoids significant steric repulsions, and the reactions are more favored. This computational analysis suggests that the DA reaction between 3 and the dienophiles in Table 4, Entries $10-13$, to yield the products analogous to $\mathbf{4}$ and $\mathbf{5}$ is thermodynamically or kinetically less favored owing to significant intramolecular steric repulsion.

\section{Aromatization of DA Adducts}

Once adducts $\mathbf{5 a - 5 e}$ were obtained, we thought it would be interesting to further aromatize them to flavone derivatives. Several methodologies using 2,3-dichloro-5,6-dicyanobenzoquinone (DDQ) have been reported;; ${ }^{[23]}$ nevertheless, our initial choice was a successful method that we employed previously for similar oxidations. ${ }^{[12]}$ Therefore, adduct $\mathbf{5 c}$ was heated in toluene at $100{ }^{\circ} \mathrm{C}$ with 3 equiv. of DDQ (Table 5, Entry 1). After $4 \mathrm{~h}$, the starting adduct $\mathbf{5 c}$ was consumed, and the oxidized product 12c was obtained in $34 \%$ yield, together with the semioxidized product 13c (NMR data in Supporting Information) in $60 \%$ yield (Table 5, Entry 1 ). With a more polar solvent, 1,4-dioxane, and an increased amount of DDQ (Table 5, Entry 2), only the semioxidized derivative 13c was obtained in $52 \%$ yield. With 1,2,4-trichlorobenzene (1,2,4-TCB) as the solvent (Table 5, Entry 3), the semioxidized derivative $13 \mathrm{c}$ was isolated in $15 \%$; however the oxidized derivative 12c was obtained in only $38 \%$ yield. The low yields of derivative $12 \mathrm{c}$ can be explained on the basis of the stability given by the presence of a conjugate diene in the semioxidized derivative 13c. Furthermore, the relatively long reaction times may contribute to the degradation of either the starting adduct or the oxidized products. MV-assisted reaction conditions were employed for the oxidation of adduct $\mathbf{5 c}$ in 1,2,4-TCB at $165^{\circ} \mathrm{C}$ for $25 \mathrm{~min}$ (Table 5, Entry 4); the desired oxidized derivative $12 \mathrm{c}$ was obtained in $90 \%$ yield, and no semioxidized product 13c was detected. These reaction conditions were also applied to adducts $\mathbf{5 a}, \mathbf{5} \mathbf{b}$, $\mathbf{5 d}$, and $\mathbf{5 e}$ to afford the oxidized products $12 \mathrm{a}, \mathbf{1 2 b}, \mathbf{1 2 d}$, and 12e (NMR data in Supporting Information) in high yields (Table 5, Entries 5-8). At this stage, derivatives 12a-12e were obtained in two steps; the intermediate DA adducts $\mathbf{5 a - 5 e}$ were isolated in the first step and further oxidized with DDQ. To address if the oxidation of adducts $\mathbf{5}$ without purification was advantageous, chromone $\mathbf{3 c}$ was reacted with NMM in the presence of $\mathrm{Sc}(\mathrm{OTf})_{3}$, and the formed adduct was oxidized with

Table 5. Aromatization of adducts $\mathbf{5 a - 5 e . ~}$<smiles>CC(C)(C)O[Na]</smiles>
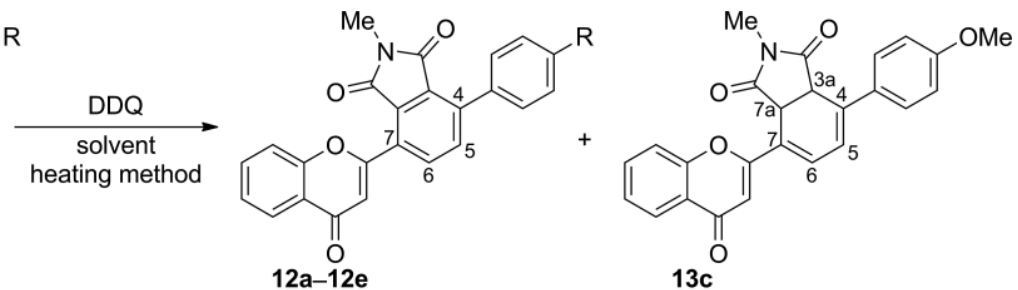

a: $\mathrm{R}=\mathrm{H}, \mathbf{b}: \mathrm{R}=\mathrm{Cl}, \mathbf{c}: \mathrm{R}=\mathrm{OMe}, \mathbf{d}: \mathrm{R}=\mathrm{Me}, \mathbf{e}: \mathrm{R}=\mathrm{NO}_{2}$

\begin{tabular}{|c|c|c|c|c|c|c|c|c|}
\hline Entry & Adduct & $\begin{array}{l}\text { DDQ } \\
\text { [equiv.] }\end{array}$ & Heating method & Solvent & $T\left[{ }^{\circ} \mathrm{C}\right]$ & Time & $\begin{array}{l}12 \\
\text { Yield [\%] }^{[\mathrm{a}]}\end{array}$ & $\begin{array}{l}13 c \\
\text { Yield }[\%]^{[a]}\end{array}$ \\
\hline 1 & $5 c$ & 3 & oil bath & toluene & 100 & $4 \mathrm{~h}$ & 34 & 60 \\
\hline 2 & $5 c$ & 5 & oil bath & 1,4-dioxane & 100 & $4 \mathrm{~h}$ & - & 52 \\
\hline 3 & $5 c$ & 3 & oil bath & $1,2,4-\mathrm{TCB}$ & 190 & $24 \mathrm{~h}$ & 38 & 15 \\
\hline 4 & $5 c$ & 4 & $\mathrm{MW}^{[\mathrm{b}]}$ & $1,2,4-\mathrm{TCB}$ & 165 & $25 \min$ & 90 & - \\
\hline 5 & $5 a$ & 4 & $\mathrm{MW}^{[\mathrm{b}]}$ & $1,2,4-\mathrm{TCB}$ & 165 & $25 \min$ & 85 & - \\
\hline 6 & $5 b$ & 4 & $\mathrm{MW}^{[\mathrm{b}]}$ & $1,2,4-\mathrm{TCB}$ & 165 & $25 \min$ & 75 & - \\
\hline 7 & $5 d$ & 4 & $\mathrm{MW}^{[\mathrm{b}]}$ & $1,2,4-\mathrm{TCB}$ & 165 & $25 \min$ & 80 & - \\
\hline 8 & $5 e$ & 4 & $\mathrm{MW}^{[\mathrm{b}]}$ & $1,2,4-\mathrm{TCB}$ & 165 & $25 \mathrm{~min}$ & 70 & - \\
\hline
\end{tabular}

[a] Isolated yield. [b] Monomode MW irradiation. 
DDQ in $1,2,4-\mathrm{TCB}$ at $165^{\circ} \mathrm{C}$ for $25 \mathrm{~min}$ in a one-pot process. The oxidized product 12c was obtained in $16 \%$ yield along with adduct $\mathbf{5 c}$ in $28 \%$ yield. The low yield of $12 \mathrm{c}$ can be explained by the chelation of the Lewis acid with the carbonyl group of adduct 5c; the chelation makes the cyclohexene ring electronpoor by conjugation, and the hydride sabstraction by DDQ is disfavored. The same experiment was performed under the same reaction conditions but in absence of the Lewis acid. Unfortunately, the reaction afforded the oxidized product $12 \mathrm{c}$ only in $20 \%$ yield, and no adduct $\mathbf{5 c}$ was isolated. In the absence of Lewis acid, the DA reaction affords more byproducts, including the bisadduct $\mathbf{7 c}$, and this may be the reason that the yield of the oxidized product $12 \mathrm{c}$ is not improved in the absence of $\mathrm{Sc}(\mathrm{OTf})_{3}$. To sum up, the one-pot DA/oxidation processes was an inefficient and disadvantageous methodology compared to the two-step procedure.

Adduct 8 was also oxidized under the best reaction conditions for adducts $\mathbf{5 a - 5 e}$ to afford derivative $\mathbf{1 4}$ in $86 \%$ yield (Scheme 5).

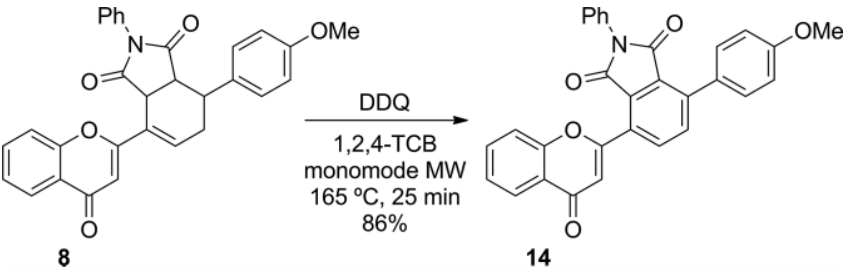

Scheme 5 . Aromatization of adduct $\mathbf{8}$.

The oxidations of cycloadducts $10 \mathrm{a}$ and $10 \mathrm{~b}$ were not straightforward, because $\mathrm{C}-\mathrm{N}$ bonds break readily upon oxidation. Therefore, the initial oxidation conditions employed to cycloadduct 10a were less harsh, and DDQ was used in 1,4dioxane at $100{ }^{\circ} \mathrm{C}$ for $24 \mathrm{~h}$. Unfortunately, no oxidized product was detected, and $72 \%$ of the starting cycloadduct 10a was recovered. Therefore, highly energetic conditions were employed with DDQ in 1,2,4-TCB at $165{ }^{\circ} \mathrm{C}$ under MV irradiation for $25 \mathrm{~min}$. Several unidentified byproducts were observed, and no oxidized product was detected.

Despite the unsuccessful attempts to oxidize cycloadduct $10 \mathrm{a}$, the aromatization of cycloadduct $\mathbf{1 0 b}$ was also attempted under MV irradiation (Scheme 6). The oxidation process occurred but was inefficient, as the oxidized product 15b was isolated in only $17 \%$ yield. In the ${ }^{1} \mathrm{H}$ NMR spectrum of derivative 15b, two broad singlets at $\delta=6.07$ and $7.88 \mathrm{ppm}$, assigned to $1-\mathrm{NH}$ and $4-\mathrm{NH}$, respectively, indicated that the $\mathrm{N}-\mathrm{N}$ single bond of the cycloadduct $\mathbf{1 0 b}$ was broken during the oxidation reaction.

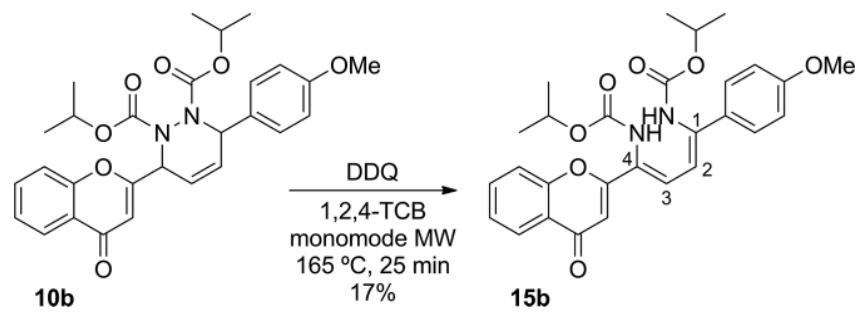

Scheme 6. Aromatization of cycloadduct 10b.

\section{Conclusions}

The $\alpha, \beta: \gamma, \delta$-diene system of chromones 3 were the most reactive in DA reactions with NMM as the dienophile to afford compounds 5, which form through a DA reaction followed by an olefin migration. These results were confirmed by computational studies, which indicated that derivative 6 (DA reaction at the 3,2: $\alpha, \beta$-diene, followed by an olefin migration) should be a minor product of DA reaction and that adducts $\mathbf{5}$ are thermodynamically more stable. However, for the DA reaction in DMF with an excess of NMM, the yields of adducts $\mathbf{5}$ were lower, and several byproducts were detected. The most relevant one resulted from a tandem DA/olefin migration/DA/olefin migration process to afford bisadduct 7 as a mixture of diastereomers. The formation of this byproduct was prevented by using $\mathrm{Sc}(\mathrm{OTf})_{3}$ under solvent-free conditions, and, consequently, adducts $\mathbf{5}$ were obtained in higher yields. An investigation of the scope of dienophiles allowed us to conclude that electron-poor dienophiles are most reactive and that no DA reaction occurred for electron-rich dienophiles. The adducts obtained with maleimides were aromatized in high yields with DDQ under MV irradiation. However, the aromatization was not straightforward for aza adducts owing to the sensitive $\mathrm{N}-\mathrm{N}$ single bonds, which were broken readily. The combination of the experimental and computational findings also indicates that the main features of the DA reactions studied are described accurately by the thermodynamic stabilities of the reaction products and intermediates and the HOMO/LUMO evaluation of the dienes and dienophiles within the frontier molecular orbitals (FMO) approach.

\section{Experimental Section}

General: The melting points were measured with a Büchi B-540 melting-point apparatus. The NMR spectra were recorded with a Bruker Avance 300 spectrometer $\left(300.13 \mathrm{MHz}\right.$ for ${ }^{1} \mathrm{H}$ and $75.47 \mathrm{MHz}$ for ${ }^{13} \mathrm{C}$ ) or Bruker Avance 500 spectrometer $\left(500.13 \mathrm{MHz}\right.$ for ${ }^{1} \mathrm{H}$ and $125.77 \mathrm{MHz}$ for $\left.{ }^{13} \mathrm{C}\right)$. Chemical shifts $(\delta)$ are reported in ppm, and coupling constants $(J)$ are in $\mathrm{Hz}$; the internal standard was tetramethylsilane (TMS). Unequivocal ${ }^{13} \mathrm{C}$ NMR assignments were made with the aid of $2 \mathrm{D}$ gradient heteronuclear single quantum coherence ( $\mathrm{gHSQC}$ ) and gradient HMBC (gHMBC; delays for one-bond long-range $\mathrm{C}-\mathrm{H}$ couplings were optimized for 145 and $7 \mathrm{~Hz}$, respectively) experiments. Positive-ion ESI mass spectra were acquired with a QTOF 2 instrument. The sample $(1 \mu \mathrm{L})$ in chloroform solution (ca. $10^{-5} \mathrm{M}$ ) was diluted in $0.1 \%$ trifluoroacetic acid/methanol solution $(200 \mu \mathrm{L})$. Nitrogen was used as nebulizer gas, and argon was used as the collision gas. The needle voltage was set to $3000 \mathrm{~V}$, the ion source was set to $80^{\circ} \mathrm{C}$, and the desolvation temperature was $150^{\circ} \mathrm{C}$. The cone voltage was $35 \mathrm{~V}$. Other low- and high-resolution mass spectra (El, $70 \mathrm{eV})$ were measured with VG Autospec $\mathrm{Q}$ and $\mathrm{M}$ spectrometers. Elemental analyses were obtained with a LECO 932 CHNS analyzer. Preparative TLC was performed with Merck silica gel (60 DGF254). Column chromatography was performed with Merck silica gel (60, 70-230 mesh). All chemicals and solvents used were obtained from commercial sources and used as received or dried by standard procedures.

General Procedure for the Synthesis of 2-[(1E,3E)-4-Arylbuta1,3-dien-1-yl]-4H-chromen-4-ones 3a-3e: Sodium $(0.11 \mathrm{~g}$, $4.8 \mathrm{mmol}$ ) was added gradually to dry ethanol $(5 \mathrm{~mL})$, and the mix- 
ture was stirred until it reached room temperature. 2-Methylchromone (1, $0.2 \mathrm{~g}, 1.2 \mathrm{mmol})$ and the appropriate cinnamaldehyde 2a-2e $(1.5 \mathrm{mmol})$ were added, and the reaction mixture was allowed to stand at room temperature until the 2-methylchromone disappeared completely. The solution was then poured into ice and water, and the $\mathrm{pH}$ was adjusted to 4 with dilute $\mathrm{HCl}$. The solid was removed by filtration, dissolved in dichloromethane, and purified by silica gel column chromatography with dichloromethane as the eluent. The solvent was evaporated, and the residue was recrystallized from ethanol to give the 2-[(1E,3E)-4-arylbuta-1,3-dien-1-yl]$4 H$-chromen-4-ones 3a-3e.

2-[(1E,3E)-4-Phenylbuta-1,3-dien-1-yl]-4H-chromen-4-one (3a): Yield $263 \mathrm{mg}(80 \%)$, orange solid, m.p. $144-146{ }^{\circ} \mathrm{C}$ (from EtOH). ${ }^{1} \mathrm{H}$ NMR (300 MHz, CDCl $): \delta=6.27(\mathrm{~s}, 1 \mathrm{H}, 3-\mathrm{H}), 6.38(\mathrm{~d}, J=15.3 \mathrm{~Hz}, 1$ $\mathrm{H}, \mathrm{H}-\alpha), 6.91-7.03(\mathrm{~m}, 2 \mathrm{H}, \mathrm{H}-\gamma, \mathrm{H}-\delta), 7.31-7.45\left(\mathrm{~m}, 6-\mathrm{H}, \mathrm{H}-\beta, 3^{\prime}, 4^{\prime}, 5^{\prime}-\right.$ H), 7.48-7.51 (m, $1 \mathrm{H}, 8-\mathrm{H}), 7.52\left(\mathrm{~d}, J=8.5 \mathrm{~Hz}, 2 \mathrm{H}, 2^{\prime}, 6^{\prime}-\mathrm{H}\right), 7.68$ (ddd, $J=8.6,7.1,1.7 \mathrm{~Hz}, 1 \mathrm{H}, 7-\mathrm{H}), 8.19$ (dd, $J=7.9,1.7 \mathrm{~Hz}, 1 \mathrm{H}, 5-$ H) ppm. ${ }^{13} \mathrm{C}$ NMR $\left(75 \mathrm{MHz}, \mathrm{CDCl}_{3}\right): \delta=110.3(\mathrm{C}-3), 117.8(\mathrm{C}-8), 123.6$ (C- $\alpha), 124.1$ (C-4a), 125.0 (C-6), 125.7 (C-5), 127.1 (C-2',6', C- $\gamma), 128.9$ $\left(C-3^{\prime}, 5^{\prime}\right), 129.0\left(\mathrm{C}-4^{\prime}\right), 133.7(\mathrm{C}-7), 136.3\left(\mathrm{C}-1^{\prime}\right), 137.4(\mathrm{C}-\beta), 139.1$ (Cठ), 156.0 (C-8a), 161.8 (C-2), 178.4 (C-4) ppm. El-MS: m/z (\%) = 274 (35) $[\mathrm{M}]^{+*}, 273$ (100) $[\mathrm{M}-\mathrm{H}]^{+}, 257$ (26), 221 (24), 197 (48). El-HRMS: calcd. for $\mathrm{C}_{19} \mathrm{H}_{14} \mathrm{O}_{2}[\mathrm{M}]^{+}$274.0994; found 274.0999.

2-[(1E,3E)-4-(4-Chlorophenyl)buta-1,3-dien-1-yl]-4H-chromen-4one (3b): Yield $259 \mathrm{mg}(70 \%)$, yellow solid, m.p. $180-182{ }^{\circ} \mathrm{C}$ (from EtOH). ${ }^{1} \mathrm{H}$ NMR (300 MHz, $\left.\mathrm{CDCl}_{3}\right): \delta=6.27(\mathrm{~s}, 1 \mathrm{H}, 3-\mathrm{H}), 6.39$ (d, $J=$ $15.2 \mathrm{~Hz}, 1 \mathrm{H}, \mathrm{H}-\alpha), 6.86-6.99(\mathrm{~m}, 2 \mathrm{H}, \mathrm{H}-\gamma, \mathrm{H}-\delta), 7.34(\mathrm{~d}, J=8.6 \mathrm{~Hz}$, $\left.2 \mathrm{H}, 3^{\prime}, 5^{\prime}-\mathrm{H}\right), 7.34-7.48(\mathrm{~m}, 2 \mathrm{H}, \mathrm{H}-\beta, 6-\mathrm{H}), 7.42(\mathrm{~d}, J=8.6 \mathrm{~Hz}, 2 \mathrm{H}$, $\left.2^{\prime}, 6^{\prime}-\mathrm{H}\right), 7.50(\mathrm{dd}, J=8.5,1.1 \mathrm{~Hz}, 1 \mathrm{H}, 8-\mathrm{H}), 7.68$ (ddd, $J=8.5,7.1$, $1.7 \mathrm{~Hz}, 1 \mathrm{H}, 7-\mathrm{H}), 8.19$ (dd, $J=7.9,1.7 \mathrm{~Hz}, 1 \mathrm{H}, 5-\mathrm{H}) \mathrm{ppm} .{ }^{13} \mathrm{C}$ NMR $\left(75 \mathrm{MHz}, \mathrm{CDCl}_{3}\right): \delta=110.5$ (C-3), 117.8 (C-8), 124.1 (C-4a), 124.2 $(\mathrm{C}-\alpha), 125.0(\mathrm{C}-6), 125.7(\mathrm{C}-5), 127.6(\mathrm{C}-\gamma), 128.2\left(\mathrm{C}-2^{\prime}, 6^{\prime}\right), 129.1$ $\left(\mathrm{C}-3^{\prime}, 5^{\prime}\right), 133.8(\mathrm{C}-7), 134.6,134.7\left(\mathrm{C}-1^{\prime}\right.$ and $\left.\mathrm{C}-4^{\prime}\right), 137.0(\mathrm{C}-\beta), 137.6$ (C- $\delta), 156.0$ (C-8a), 161.6 (C-2), 178.4 (C-4) ppm. El-MS: $\mathrm{m} / \mathrm{z}(\%)=$ $310\left({ }^{37} \mathrm{Cl}, 9\right)[\mathrm{M}+\mathrm{H}]^{+}, 309\left({ }^{37} \mathrm{Cl}, 23\right)[\mathrm{M}]^{+*}, 308\left({ }^{35} \mathrm{Cl}, 28\right)[\mathrm{M}+\mathrm{H}]^{+}$, $307\left({ }^{35} \mathrm{Cl}, 100\right)[\mathrm{M}]^{+*}, 291$ (20), 197 (35), 152 (24). El-HRMS: calcd. for $\mathrm{C}_{19} \mathrm{H}_{12}{ }^{35} \mathrm{ClO}_{2}[\mathrm{M}-\mathrm{H}]^{+}$307.0526; found 307.0567.

2-[(1E,3E)-4-(4-Methoxyphenyl)buta-1,3-dien-1-yl]-4H-chromen-4-one (3c): Yield $292 \mathrm{mg}(80 \%)$, yellow solid, m.p. $137-139{ }^{\circ} \mathrm{C}$ (from EtOH). ${ }^{1} \mathrm{H}$ NMR (300 MHz, $\left.\mathrm{CDCl}_{3}\right): \delta=3.84\left(\mathrm{~s}, 3 \mathrm{H}, \mathrm{OCH}_{3}\right), 6.24$ $(\mathrm{s}, 1 \mathrm{H}, 3-\mathrm{H}), 6.32(\mathrm{~d}, J=15.3 \mathrm{~Hz}, 1 \mathrm{H}, \mathrm{H}-\alpha), 6.84-6.87(\mathrm{~m}, 1 \mathrm{H}, \mathrm{H}-\delta)$, $6.90\left(\mathrm{~d}, J=8.8 \mathrm{~Hz}, 2 \mathrm{H}, 3^{\prime}, 5^{\prime}-\mathrm{H}\right), 6.90-6.96(\mathrm{~m}, 1 \mathrm{H}, \mathrm{H}-\gamma), 7.38$ (ddd, $J=8.2,7.1,0.9 \mathrm{~Hz}, 1 \mathrm{H}, 6-\mathrm{H}), 7.41-7.44(\mathrm{~m}, 1 \mathrm{H}, \mathrm{H}-\beta), 7.43(\mathrm{~d}, J=$ $\left.8.8 \mathrm{~Hz}, 2 \mathrm{H}, 2^{\prime}, 6^{\prime}-\mathrm{H}\right), 7.49(\mathrm{~d}, J=8.1 \mathrm{~Hz}, 1 \mathrm{H}, 8-\mathrm{H}), 7.67$ (ddd, $J=8.1$, 7.1, 1.7 Hz, $1 \mathrm{H}, 7-\mathrm{H}), 8.18$ (dd, $J=8.2,1.7 \mathrm{~Hz}, 1 \mathrm{H}, 5-\mathrm{H}) \mathrm{ppm} .{ }^{13} \mathrm{C}$ NMR $\left(75 \mathrm{MHz}, \mathrm{CDCl}_{3}\right): \delta=55.3\left(\mathrm{OCH}_{3}\right), 109.9(\mathrm{C}-3), 114.3\left(\mathrm{C}-3^{\prime}, 5^{\prime}\right)$, 117.7 (C-8), $122.3(\mathrm{C}-\alpha), 124.1$ (C-4a), 124.8 (C-6), 125.0 (C- $\gamma), 125.5$ $(\mathrm{C}-5), 128.5\left(\mathrm{C}-2^{\prime}, 6^{\prime}\right), 128.6\left(\mathrm{C}-1^{\prime}\right), 133.6(\mathrm{C}-7), 137.8(\mathrm{C}-\beta), 138.9$ (Cठ), 140.4 (C-8a), 160.3 (C-4'), 162.0 (C-2), 178.4 (C-4) ppm. El-MS: m/z $(\%)=304(68)[\mathrm{M}]^{+*}, 303(100)[\mathrm{M}-\mathrm{H}]^{+}, 287$ (27), 197 (23). El-HRMS: calcd. for $\mathrm{C}_{20} \mathrm{H}_{16} \mathrm{O}_{3}[\mathrm{M}]^{+}$304.1099; found 304.1098.

2-[(1E,3E)-4-(4-Methylphenyl)buta-1,3-dien-1-yl]-4H-chromen4-one (3d): Yield $266 \mathrm{mg}$ (77\%), orange solid, m.p. $144-147{ }^{\circ} \mathrm{C}$ (from EtOH). ${ }^{1} \mathrm{H}$ NMR (300 MHz, $\left.\mathrm{CDCl}_{3}\right): \delta=2.37\left(\mathrm{~s}, 3 \mathrm{H}, \mathrm{CH}_{3}\right), 6.25$ $(\mathrm{s}, 1 \mathrm{H}, 3-\mathrm{H}), 6.35(\mathrm{~d}, J=15.2 \mathrm{~Hz}, 1 \mathrm{H}, \mathrm{H}-\alpha), 6.88-6.99(\mathrm{~m}, 2 \mathrm{H}, \mathrm{H}-\gamma$, $\mathrm{H}-\delta), 7.19\left(\mathrm{~d}, J=8.0 \mathrm{~Hz}, 2 \mathrm{H}, 3^{\prime}, 5^{\prime}-\mathrm{H}\right), 7.36-7.46(\mathrm{~m}, 2 \mathrm{H}, \mathrm{H}-\beta, 6-\mathrm{H})$, $7.39\left(\mathrm{~d}, J=8.0 \mathrm{~Hz}, 2 \mathrm{H}, 2^{\prime}, 6^{\prime}-\mathrm{H}\right), 7.49(\mathrm{dd}, J=8.5,1.0 \mathrm{~Hz}, 1 \mathrm{H}, 8-\mathrm{H})$, 7.67 (ddd, $J=8.5,7.1,1.6 \mathrm{~Hz}, 1 \mathrm{H}, 7-\mathrm{H}), 8.19$ (dd, $J=8.0,1.6 \mathrm{~Hz}, 1$ $\mathrm{H}, 5-\mathrm{H}) \mathrm{ppm} .{ }^{13} \mathrm{C}$ NMR $\left(75 \mathrm{MHz}, \mathrm{CDCl}_{3}\right): \delta=21.4\left(\mathrm{CH}_{3}\right), 110.1(\mathrm{C}-3)$, 117.8 (C-8), 123.0 (C- $\alpha), 124.1$ (C-4a), 124.9 (C-6), 125.7 (C-5), 126.2 $(C-\gamma), 127.1\left(C-2^{\prime}, 6^{\prime}\right), 129.6\left(C-3^{\prime}, 5^{\prime}\right), 133.5\left(C-1^{\prime}\right), 133.6(C-7), 137.7$ $(C-\beta), 139.2\left(C-\delta, C-4^{\prime}\right), 156.0$ (C-8a), 161.9 (C-2), 178.4 (C-4) ppm. El-
MS: $m / z(\%)=288(40)[\mathrm{M}]^{+\cdot}, 287(100)[\mathrm{M}-\mathrm{H}]^{+}, 271(22), 197$ (33). El-HRMS: calcd. for $\mathrm{C}_{20} \mathrm{H}_{16} \mathrm{O}_{2}[\mathrm{M}]^{+}$288.1150; found 288.1149.

2-[(1E,3E)-4-(4-Nitrophenyl)buta-1,3-dien-1-yl]-4H-chromen-4one (3e): Yield $260 \mathrm{mg}$ (68\%), yellow solid, m.p. $198-200{ }^{\circ} \mathrm{C}$ (from EtOH). ${ }^{1} \mathrm{H}$ NMR $\left(300 \mathrm{MHz}, \mathrm{CDCl}_{3}\right): \delta=6.32(\mathrm{~s}, 1 \mathrm{H}, 3-\mathrm{H}), 6.51(\mathrm{~d}, J=$ $15.2 \mathrm{~Hz}, 1 \mathrm{H}, \mathrm{H}-\alpha), 6.95-7.15(\mathrm{~m}, 2 \mathrm{H}, \mathrm{H}-\gamma, \mathrm{H}-\delta), 7.38-7.48(\mathrm{~m}, 2 \mathrm{H}$, $\mathrm{H}-\beta, 6-\mathrm{H}), 7.51(\mathrm{dd}, J=8.7,1.0 \mathrm{~Hz}, 1 \mathrm{H}, 8-\mathrm{H}), 7.62(\mathrm{~d}, J=8.8 \mathrm{~Hz}, 2$ $\left.\mathrm{H}, 2^{\prime}, 6^{\prime}-\mathrm{H}\right), 7.70$ (ddd, $\left.J=8.7,7.1,1.7 \mathrm{~Hz}, 1 \mathrm{H}, 7-\mathrm{H}\right), 8.20$ (dd, $J=7.9$, $1.7 \mathrm{~Hz}, 1 \mathrm{H}, 5-\mathrm{H}), 8.24\left(\mathrm{~d}, J=8.8 \mathrm{~Hz}, 2 \mathrm{H}, 3^{\prime}, 5^{\prime}-\mathrm{H}\right) \mathrm{ppm} .{ }^{13} \mathrm{C}$ NMR (75 MHz, CDCl $): \delta=111.3(\mathrm{C}-3), 117.8(\mathrm{C}-8), 124.1$ (C-4a), $124.3(\mathrm{C}-$ $\left.3^{\prime} 5^{\prime}\right), 125.2$ (C-6), $125.8(C-5), 126.5(C-\alpha), 127.4\left(C-2^{\prime}, 6^{\prime}\right), 131.2(C-\gamma)$, 133.9 (C-7), 135.89, 135.94 (C- $\beta$ and $C-\delta), 142.5$ (C-1'), $147.4\left(C-4^{\prime}\right)$, 156.0 (C-8a), 161.0 (C-2), 178.5 (C-4) ppm. El-MS: $m / z(\%)=319$ (57) $[\mathrm{M}+\mathrm{H}]^{+}, 318(100)[\mathrm{M}]^{+*}, 289$ (50), 288 (35), 272 (33), 197 (73), 152 (27). El-HRMS: calcd. for $\mathrm{C}_{19} \mathrm{H}_{12} \mathrm{NO}_{4}[\mathrm{M}-\mathrm{H}]^{+} 318.0766$; found 318.0765

4-(4-Methoxyphenyl)-2-methyl-7-(4-oxo-4H-chromen-2-yl)3a,4,7,7a-tetrahydro-1H-isoindole-1,3(2H)-dione (4c): This compound was isolated from the reaction of $3 c(37 \mathrm{mg}, 0.121 \mathrm{mmol})$ with NMM (134 mg, $1.21 \mathrm{mmol})$ in dry DMF $(10 \mu \mathrm{L})$ at $130{ }^{\circ} \mathrm{C}$ for $10 \mathrm{~min}$ in a multimode MV apparatus, and the residue was purified by preparative TLC with ethyl acetate/hexane (1:1) as the eluent. (4 mg, 8 \%). ${ }^{1} \mathrm{H}$ NMR (300 MHz, $\mathrm{CDCl}_{3}$ ): $\delta=2.57$ (s, $3 \mathrm{H}, \mathrm{NCH}_{3}$ ), 3.40$3.49(\mathrm{~m}, 2 \mathrm{H}, 3 \mathrm{a}-\mathrm{H}, 7 \mathrm{a}-\mathrm{H}), 3.78\left(\mathrm{~s}, 3 \mathrm{H}, \mathrm{OCH}_{3}\right), 3.95-3.99(\mathrm{~m}, 1 \mathrm{H}, 4-$ $\mathrm{H}), 4.25-4.27(\mathrm{~m}, 1 \mathrm{H}, 7-\mathrm{H}), 6.14$ (ddd, $J=9.9,4.4,1.9 \mathrm{~Hz}, 1 \mathrm{H}, 6-\mathrm{H})$, 6.33 (ddd, $J=9.9,5.0,2.0 \mathrm{~Hz}, 1 \mathrm{H}, 5-\mathrm{H}), 6.40\left(\mathrm{~s}, 1 \mathrm{H}, 3^{\prime}-\mathrm{H}\right), 6.83$ (d, $\left.J=8.7 \mathrm{~Hz}, 2 \mathrm{H}, 3^{\prime \prime}, 5^{\prime \prime}-\mathrm{H}\right), 7.00$ (d, J= $\left.8.7 \mathrm{~Hz}, 2 \mathrm{H}, 2^{\prime \prime}, 6^{\prime \prime}-\mathrm{H}\right), 7.43$ (ddd, $\left.J=8.0,7.1,1.1 \mathrm{~Hz}, 1 \mathrm{H}, 6^{\prime}-\mathrm{H}\right), 7.48\left(\mathrm{dd}, J=8.3,1.1 \mathrm{~Hz}, 1 \mathrm{H}, 8^{\prime}-\mathrm{H}\right)$, 7.70 (ddd, $J=8.3,7.1,1.7 \mathrm{~Hz}, 1 \mathrm{H}, 7^{\prime}-\mathrm{H}$ ), 8.21 (dd, $J=8.0,1.7 \mathrm{~Hz}, 1$ $\left.\mathrm{H}, 5^{\prime}-\mathrm{H}\right)$ ppm. ${ }^{13} \mathrm{C}$ NMR $\left(75 \mathrm{MHz}, \mathrm{CDCl}_{3}\right): \delta=24.4\left(\mathrm{NCH}_{3}\right), 37.3(\mathrm{C}-7)$, $39.0(\mathrm{C}-4), 42.3(\mathrm{C}-7 \mathrm{a}), 44.1(\mathrm{C}-3 \mathrm{a}), 55.2\left(\mathrm{OCH}_{3}\right), 109.8\left(\mathrm{C}-3^{\prime}\right), 113.8$ $\left(\mathrm{C}-3^{\prime \prime}, 5^{\prime \prime}\right), 117.9\left(\mathrm{C}-6^{\prime}\right), 123.7$ (C-4'a), $125.0(\mathrm{C}-6), 125.4\left(\mathrm{C}-6^{\prime}\right), 125.9$ $\left(\mathrm{C}-5^{\prime}\right), 129.2\left(\mathrm{C}-1^{\prime \prime}\right), 129.9\left(\mathrm{C}-2^{\prime \prime}, 6^{\prime \prime}\right), 132.6(\mathrm{C}-5), 133.9\left(\mathrm{C}-7^{\prime}\right), 156.7$ (C-8'a), 159.0 (C-4"), 167.9 (C-2'), 176.5, 177.4 (C-1 and C-3), 178.2 (C-4') ppm.

General Procedure for the Synthesis of 2-Methyl-7-(4-oxo-4Hchromen-2-yl)-4-aryl-3a, 4, 5,7a-tetrahydro- $1 \mathrm{H}$-isoindole1,3(2H)-diones 5a-5e: NMM (40.3 mg, $0.363 \mathrm{mmol}), \mathrm{Sc}(\mathrm{OTf})_{3}$ (59.5 $\mathrm{mg}, 0.121 \mathrm{mmol}$ ), and the appropriate chromone $\mathbf{3 a} \mathbf{a} \mathbf{3 e}$ $(0.121 \mathrm{mmol})$ were mixed in a closed vessel. The resulting mixture was heated at $165^{\circ} \mathrm{C}$ under MV irradiation (monomode apparatus) for $10 \mathrm{~min}$. The residue was dissolved in dichloromethane and purified by preparative TLC with ethyl acetate/hexane (1:1) as the eluent.

2-Methyl-7-(4-oxo-4H-chromen-2-yl)-4-phenyl-3a,4,5,7a-tetrahydro-1 $\mathrm{H}$-isoindole-1,3(2H)-dione (5a): Yield $36 \mathrm{mg}(77 \%)$, white solid, m.p. $220-223{ }^{\circ} \mathrm{C} .{ }^{1} \mathrm{H}$ NMR $\left(300 \mathrm{MHz}, \mathrm{CDCl}_{3}\right): \delta=2.59(\mathrm{~s}, 3 \mathrm{H}$, $\left.\mathrm{NCH}_{3}\right), 2.76-2.82(\mathrm{~m}, 2 \mathrm{H}, 5-\mathrm{H}), 3.49(\mathrm{q}, J=5.8 \mathrm{~Hz}, 1 \mathrm{H}, 4-\mathrm{H}), 3.60$ (dd, J = 7.9, $5.8 \mathrm{~Hz}, 1 \mathrm{H}, 3 \mathrm{a}-\mathrm{H}), 4.15$ (dd, $J=7.9,1.5 \mathrm{~Hz}, 1 \mathrm{H}, 7 \mathrm{a}-\mathrm{H})$, 6.65 (s, $\left.1 \mathrm{H}, 3^{\prime}-\mathrm{H}\right), 7.24-7.33\left(\mathrm{~m}, 5 \mathrm{H}, 2^{\prime \prime}, 3^{\prime \prime}, 4^{\prime \prime}, 5^{\prime \prime}, 6^{\prime \prime}-\mathrm{H}, 6-\mathrm{H}\right), 7.41$ (ddd, $J=8.0,7.1,0.8 \mathrm{~Hz}, 1 \mathrm{H}, 6^{\prime}-\mathrm{H}$ ), 7.48 (dd, $J=8.5,0.8 \mathrm{~Hz}, 1 \mathrm{H}, 8^{\prime}-$ H), 7.68 (ddd, $\left.J=8.5,7.1,1.6 \mathrm{~Hz}, 1 \mathrm{H}, 7^{\prime}-\mathrm{H}\right), 8.21(\mathrm{dd}, J=8.0,1.6 \mathrm{~Hz}$, $\left.1 \mathrm{H}, 5^{\prime}-\mathrm{H}\right)$ ppm. ${ }^{13} \mathrm{C}$ NMR (125 MHz, $\left.\mathrm{CDCl}_{3}\right): \delta=24.4\left(\mathrm{NCH}_{3}\right), 28.5$ (C-5), 38.2 (C-4), 40.6 (C-7a), 45.2 (C-3a), 109.0 (C-3'), 117.9 (C-8'), 124.0 (C-4'a), 125.2 (C-6), 125.7 (C-6'), $126.8\left(\mathrm{C}-5^{\prime}\right), 127.5$ (C-7), 128.0 $\left(\mathrm{C}-2^{\prime \prime}, 6^{\prime \prime}\right), 128.5\left(\mathrm{C}-3^{\prime \prime}, 5^{\prime \prime}\right), 133.8\left(\mathrm{C}-7^{\prime}\right), 135.9\left(\mathrm{C}-4^{\prime \prime}\right), 139.4\left(\mathrm{C}-1^{\prime \prime}\right)$, 156.0 (C-8'a), 161.9 (C-2'), 174.0 (C-1), 176.3 (C-3), 178.5 (C-4') ppm. El-MS: $m / z(\%)=386(24)[\mathrm{M}+\mathrm{H}]^{+}, 385(100)\left[\mathrm{M}^{+}, 274(21), 273\right.$ (34). El-HRMS: calcd. for $\mathrm{C}_{24} \mathrm{H}_{19} \mathrm{NO}_{4}[\mathrm{M}]^{+} 385.1314$; found 385.1319 .

4-(4-Chlorophenyl)-2-methyl-7-(4-oxo-4H-chromen-2-yl)$3 a, 4,5,7 a-t e t r a h y d r o-1 H$-isoindole-1,3(2H)-dione $(5 b)$ : Yield 
$28 \mathrm{mg}$ (55\%), white solid, m.p. 209-211 ${ }^{\circ} \mathrm{C} .{ }^{1} \mathrm{H}$ NMR $(300 \mathrm{MHz}$, $\left.\mathrm{CDCl}_{3}\right): \delta=2.68\left(\mathrm{~s}, 3 \mathrm{H}, \mathrm{NCH}_{3}\right), 2.68-2.79(\mathrm{~m}, 2 \mathrm{H}, 5-\mathrm{H}), 3.42(\mathrm{dt}, J=$ 7.8, $5.4 \mathrm{~Hz}, 1 \mathrm{H}, 4-\mathrm{H}), 3.59$ (dd, J = 8.1, $5.4 \mathrm{~Hz}, 1 \mathrm{H}, 3 \mathrm{a}-\mathrm{H}), 4.19$ (dd, $J=8.1,1.7 \mathrm{~Hz}, 1 \mathrm{H}, 7 \mathrm{a}-\mathrm{H}), 6.65\left(\mathrm{~s}, 1 \mathrm{H}, 3^{\prime}-\mathrm{H}\right), 7.21(\mathrm{~d}, J=8.6 \mathrm{~Hz}, 2$ $\left.\mathrm{H}, 3^{\prime \prime}, 5^{\prime \prime}-\mathrm{H}\right), 7.20-7.24(\mathrm{~m}, 1 \mathrm{H}, 6-\mathrm{H}), 7.29\left(\mathrm{~d}, J=8.6 \mathrm{~Hz}, 2 \mathrm{H}, 2^{\prime \prime}, 6^{\prime \prime}-\right.$ H), 7.41 (ddd, $\left.J=8.0,7.1,1.0 \mathrm{~Hz}, 1 \mathrm{H}, 6^{\prime}-\mathrm{H}\right), 7.47$ (dd, $J=8.5,1.0 \mathrm{~Hz}$, $\left.1 \mathrm{H}, 8^{\prime}-\mathrm{H}\right), 7.69$ (ddd, $\left.J=8.5,7.1,1.7 \mathrm{~Hz}, 1 \mathrm{H}, 7^{\prime}-\mathrm{H}\right), 8.22$ (dd, $J=8.0$, $\left.1.7 \mathrm{~Hz}, 1 \mathrm{H}, 5^{\prime}-\mathrm{H}\right)$ ppm. ${ }^{13} \mathrm{C}$ NMR $\left(75 \mathrm{MHz}, \mathrm{CDCl}_{3}\right): \delta=24.5\left(\mathrm{NCH}_{3}\right)$, 28.1 (C-5), 37.8 (C-4), 40.9 (C-7a), 45.0 (C-3a), 109.2 (C-3'), 117.8 (C-8'), 124.0 (C-4'a), 125.2 (C-6'), 125.8 (C-5'), 127.0 (C-7), 128.6 $\left(\mathrm{C}-2^{\prime \prime}, 6^{\prime \prime}\right), 129.3\left(\mathrm{C}-3^{\prime \prime}, 5^{\prime \prime}\right), 133.3\left(\mathrm{C}-1^{\prime \prime}\right), 133.9\left(\mathrm{C}-7^{\prime}\right), 135.5(\mathrm{C}-6), 138.0$ (C-4") 156.0 (C-8'a), 161.6 (C-2'), 173.9 (C-3), 176.0 (C-1), 178.4 (C-4') ppm. El-MS: $m / z(\%)=421\left({ }^{37} \mathrm{Cl}, 23\right)\left[\mathrm{M}^{+*}, 419\left({ }^{35} \mathrm{Cl}, 100\right)\right.$ $[\mathrm{M}]^{+\cdot}$. El-HRMS $\mathrm{m} / \mathrm{z}$ calcd. for $\mathrm{C}_{24} \mathrm{H}_{18}{ }^{35} \mathrm{CINO}_{4}[\mathrm{M}]^{+} 419.0924$; found 419.0938 .

4-(4-Methoxyphenyl)-2-methyl-7-(4-oxo-4H-chromen-2-yl)3a, 4,5,7a-tetrahydro- $\mathbf{H}$-isoindole-1,3(2H)-dione $(5 \mathrm{c})$ : Yield $34 \mathrm{mg}$ (67\%), white solid, m.p. 222-224 ${ }^{\circ} \mathrm{C} .{ }^{1} \mathrm{H}$ NMR $(300 \mathrm{MHz}$, $\left.\mathrm{CDCl}_{3}\right): \delta=2.60\left(\mathrm{~s}, 3 \mathrm{H}, \mathrm{NCH}_{3}\right), 2.73-2.80(\mathrm{~m}, 2 \mathrm{H}, 5-\mathrm{H}), 3.46(\mathrm{q}, J=$ $5.7 \mathrm{~Hz}, 1 \mathrm{H}, 4-\mathrm{H}), 3.55$ (dd, J= 7.8, $5.7 \mathrm{~Hz}, 1 \mathrm{H}, 3 \mathrm{a}-\mathrm{H}), 3.77(\mathrm{~s}, 3 \mathrm{H}$, $\left.\mathrm{OCH}_{3}\right), 4.12(\mathrm{dd}, J=7.8,1.4 \mathrm{~Hz}, 1 \mathrm{H}, 7 \mathrm{a}-\mathrm{H}), 6.63\left(\mathrm{~s}, 1 \mathrm{H}, 3^{\prime}-\mathrm{H}\right), 6.82$ (d, J = 8.7 Hz, $\left.2 \mathrm{H}, 3^{\prime \prime}, 5^{\prime \prime}-\mathrm{H}\right), 7.17\left(\mathrm{~d}, J=8.7 \mathrm{~Hz}, 2 \mathrm{H}, 2^{\prime \prime}, 6^{\prime \prime}-\mathrm{H}\right), 7.24$ $(\mathrm{td}, J=4.8,1.4 \mathrm{~Hz}, 1 \mathrm{H}, 6-\mathrm{H}), 7.40$ (ddd, $J=7.7,7.3,0.8 \mathrm{~Hz}, 1 \mathrm{H}, 6^{\prime}-$ H), 7.47 (dd, $\left.J=8.3,0.8 \mathrm{~Hz}, 1 \mathrm{H}, 8^{\prime}-\mathrm{H}\right), 7.68(\mathrm{ddd}, J=8.3,7.3,1.6 \mathrm{~Hz}$, $\left.1 \mathrm{H}, 7^{\prime}-\mathrm{H}\right), 8.21$ (dd, $\left.J=7.7,1.6 \mathrm{~Hz}, 1 \mathrm{H}, 5^{\prime}-\mathrm{H}\right) \mathrm{ppm} .{ }^{13} \mathrm{C}$ NMR $(75 \mathrm{MHz}$, $\left.\mathrm{CDCl}_{3}\right): \delta=24.4\left(\mathrm{NCH}_{3}\right), 29.0(\mathrm{C}-5), 37.5(\mathrm{C}-4), 40.4$ (C-7a), 45.2 $(\mathrm{C}-3 \mathrm{a}), 55.2\left(\mathrm{OCH}_{3}\right), 109.0\left(\mathrm{C}-3^{\prime}\right), 113.8\left(\mathrm{C}-3^{\prime \prime}, 5^{\prime \prime}\right), 117.9\left(\mathrm{C}-8^{\prime}\right), 124.0$ (C-4'a), 125.1 (C-6'), 125.7 (C-5'), 126.7 (C-7), 129.1 (C-2",6" $\left.{ }^{\prime \prime}\right), 131.2$ $\left(\mathrm{C}-1^{\prime \prime}\right), 133.8\left(\mathrm{C}-7^{\prime}\right), 135.9$ (C-6), 156.0 (C-8'a), $158.8\left(\mathrm{C}-4^{\prime \prime}\right), 162.0$ (C$\left.2^{\prime}\right), 174.1$ (C-1), 176.5 (C-3), 178.5 (C-4') ppm. El-MS: m/z (\%) = 415 (5) $\left[\mathrm{M}^{+*}, 385\right.$ (26), 381 (100), 353 (27), 352 (22). El-HRMS: calcd. for $\mathrm{C}_{25} \mathrm{H}_{21} \mathrm{NO}_{5}[\mathrm{M}]^{+}$415.1420; found 415.1427.

2-Methyl-7-(4-oxo-4H-chromen-2-yl)-4-(4-methylphenyl)3a,4,5,7a-tetrahydro- $\mathbf{H}$-isoindole-1,3(2H)-dione $(5 \mathrm{~d})$ : Yield $34 \mathrm{mg}$ (71\%), white solid, m.p. 223-225 ${ }^{\circ} \mathrm{C} .{ }^{1} \mathrm{H}$ NMR $(300 \mathrm{MHz}$, $\left.\mathrm{CDCl}_{3}\right): \delta=2.31\left(\mathrm{~s}, 3 \mathrm{H}, \mathrm{CH}_{3}\right), 2.61\left(\mathrm{~s}, 3 \mathrm{H}, \mathrm{NCH}_{3}\right), 2.73-2.80(\mathrm{~m}, 2 \mathrm{H}$, 5-H), 3.45 (q, J= $5.7 \mathrm{~Hz}, 1 \mathrm{H}, 4-\mathrm{H}), 3.57$ (dd, J= 7.9, $5.7 \mathrm{~Hz}, 1 \mathrm{H}, 3 \mathrm{a}-$ $\mathrm{H}), 4.14(\mathrm{dd}, J=7.9,1.4 \mathrm{~Hz}, 1 \mathrm{H}, 7 \mathrm{a}-\mathrm{H}), 6.65\left(\mathrm{~s}, 1 \mathrm{H}, 3^{\prime}-\mathrm{H}\right), 7.10,7.15$ $\left(J=8.5 \mathrm{~Hz}, 4 \mathrm{H}, 3^{\prime \prime}, 5^{\prime \prime}-\mathrm{H} ; 2^{\prime \prime}, 6^{\prime \prime}-\mathrm{H}, \mathrm{AA}^{\prime} \mathrm{BB}^{\prime}\right), 7.23-7.26(\mathrm{~m}, 1 \mathrm{H}, 6-\mathrm{H})$, 7.41 (ddd, $J=7.7,7.3,1.0 \mathrm{~Hz}, 1 \mathrm{H}, 6^{\prime}-\mathrm{H}$ ), 7.47 (dd, $J=8.2,1.0 \mathrm{~Hz}, 1$ $\left.\mathrm{H}, 8^{\prime}-\mathrm{H}\right), 7.68$ (ddd, $\left.J=8.2,7.3,1.6 \mathrm{~Hz}, 1 \mathrm{H}, 7^{\prime}-\mathrm{H}\right), 8.21$ (dd, $J=7.7$, $\left.1.6 \mathrm{~Hz}, 1 \mathrm{H}, 5^{\prime}-\mathrm{H}\right) \mathrm{ppm} .{ }^{13} \mathrm{C} \mathrm{NMR}\left(75 \mathrm{MHz}, \mathrm{CDCl}_{3}\right): \delta=21.0\left(\mathrm{CH}_{3}\right)$, $24.4\left(\mathrm{NCH}_{3}\right), 28.5(\mathrm{C}-5), 37.9(\mathrm{C}-4), 40.6$ (C-7a), 45.2 (C-3a), 109.0 (C$\left.3^{\prime}\right), 117.9\left(\mathrm{C}-8^{\prime}\right), 124.0\left(\mathrm{C}-4^{\prime} \mathrm{a}\right), 125.1\left(\mathrm{C}-6^{\prime}\right), 125.7\left(\mathrm{C}-5^{\prime}\right), 126.7(\mathrm{C}-7)$,

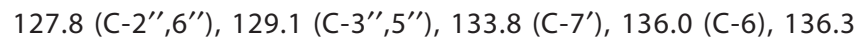
$\left(\mathrm{C}-1^{\prime \prime}\right), 137.1\left(\mathrm{C}-4^{\prime \prime}\right), 156.0$ (C-8'a), $162.0\left(\mathrm{C}-2^{\prime}\right), 174.1$ (C-1), 176.3 (C-3), $178.5\left(\mathrm{C}-4^{\prime}\right)$ ppm. El-MS: $m / z(\%)=400(23)[\mathrm{M}+\mathrm{H}]^{+}, 399$ (100) $[\mathrm{M}]^{+*}, 395$ (26), 287 (32). El-HRMS: calcd. for $\mathrm{C}_{25} \mathrm{H}_{21} \mathrm{NO}_{4}[\mathrm{M}]^{+}$ 399.1471; found 399.1476.

2-Methyl-4-(4-nitrophenyl)-7-(4-oxo-4H-chromen-2-yl)3a, 4,5,7a-tetrahydro- $\mathbf{H}$-isoindole-1,3(2H)-dione (5e): Yield $27 \mathrm{mg}$ (52\%), white solid, m.p. 162-165 ${ }^{\circ} \mathrm{C} .{ }^{1} \mathrm{H}$ NMR $(300 \mathrm{MHz}$, $\left.\mathrm{CDCl}_{3}\right): \delta=2.78\left(\mathrm{~s}, 3 \mathrm{H}, \mathrm{NCH}_{3}\right), 2.73-2.82(\mathrm{~m}, 2 \mathrm{H}, 5-\mathrm{H}), 3.46(\mathrm{dt}, J=$ 9.8, 5.1 Hz, $1 \mathrm{H}, 4-\mathrm{H}$ ), 3.71 (ddd, J=8.1, 5.1, $1.3 \mathrm{~Hz}, 1 \mathrm{H}, 3 \mathrm{a}-\mathrm{H}$ ), 4.31 $(\mathrm{d}, J=8.1 \mathrm{~Hz}, 1 \mathrm{H}, 7 \mathrm{a}-\mathrm{H}), 6.70\left(\mathrm{~s}, 1 \mathrm{H}, 3^{\prime}-\mathrm{H}\right), 7.23$ (ddd, $J=6.3,3.5$, $1.1 \mathrm{~Hz}, 1 \mathrm{H}, 6-\mathrm{H}), 7.42$ (ddd, $\left.J=8.1,7.1,1.1 \mathrm{~Hz}, 1 \mathrm{H}, 6^{\prime}-\mathrm{H}\right), 7.44-7.49$ (m, $\left.1 \mathrm{H}, 8^{\prime}-\mathrm{H}\right), 7.50\left(\mathrm{~d}, J=8.6 \mathrm{~Hz}, 2 \mathrm{H}, 2^{\prime \prime}, 6^{\prime \prime}-\mathrm{H}\right), 7.70$ (ddd, $J=8.7$, 7.1, $\left.1.7 \mathrm{~Hz}, 1 \mathrm{H}, 7^{\prime}-\mathrm{H}\right), 8.20-8.23\left(\mathrm{~m}, 1 \mathrm{H}, 5^{\prime}-\mathrm{H}\right), 8.22(\mathrm{~d}, J=8.6 \mathrm{~Hz}, 2$ $\left.\mathrm{H}, 3^{\prime \prime}, 5^{\prime \prime}-\mathrm{H}\right)$ ppm. ${ }^{13} \mathrm{C}$ NMR (75 MHz, $\left.\mathrm{CDCl}_{3}\right): \delta=24.8\left(\mathrm{NCH}_{3}\right), 26.9$ (C-5), 38.5 (C-4), 41.6 (C-7a), 45.0 (C-3a), 109.4 (C-3'), 117.8 (C-8'), $123.6\left(\mathrm{C}-3^{\prime \prime}, 5^{\prime \prime}\right), 123.9$ (C-4'a), $125.3\left(\mathrm{C}-6^{\prime}\right), 125.8$ (C-5'), 127.5 (C-7), $128.8\left(\mathrm{C}-2^{\prime \prime}, 6^{\prime \prime}\right), 134.0\left(\mathrm{C}-7^{\prime}\right), 135.0(\mathrm{C}-6), 147.1\left(\mathrm{C}-4^{\prime \prime}\right), 147.4\left(\mathrm{C}-\mathrm{-}^{\prime \prime}\right)$,
155.9 (C-8'a), 161.1 (C-2'), 173.6 (C-1), 175.5 (C-3), 178.4 (C-4') ppm. El-MS: $m / z(\%)=430(62)\left[\mathrm{M}^{+*}, 400\right.$ (100), 396 (50), 383 (30), 368 (34). El-HRMS: calcd. for $\mathrm{C}_{24} \mathrm{H}_{18} \mathrm{~N}_{2} \mathrm{O}_{6}[\mathrm{M}]^{+} 430.1165$; found 430.1161.

(E)-4-(4-Methoxystyryl)-2-methyl-3a,4,5,11 b-tetrahydrochromeno[3,2-e]isoindole-1,3,11(2H)-trione (6c): This compound was isolated from the reaction of $3 \mathrm{c}(37 \mathrm{mg}, 0.121 \mathrm{mmol})$ with NMM (67 mg, $0.605 \mathrm{mmol})$ in dry DMF $(10 \mu \mathrm{L})$ at $160{ }^{\circ} \mathrm{C}$ for $10 \mathrm{~min}$ in a multimode MV apparatus, and the residue was purified by preparative TLC with ethyl acetate/hexane (1:1) as the eluent. Yield $3 \mathrm{mg}$ (6\%). ${ }^{1} \mathrm{H}$ NMR $\left(500 \mathrm{MHz}, \mathrm{CDCl}_{3}\right): \delta=2.73$ (dd, $J=17.3,7.4 \mathrm{~Hz}, 1 \mathrm{H}$, 5-H), 2.87 (s, $3 \mathrm{H}, \mathrm{NCH}_{3}$ ), 2.95 (dd, $\left.J=17.3,4.2 \mathrm{~Hz}, 1 \mathrm{H}, 5-\mathrm{H}\right), 3.11-$ $3.16(\mathrm{~m}, 1 \mathrm{H}, 4-\mathrm{H}), 3.37(\mathrm{dd}, J=8.2,5.3 \mathrm{~Hz}, 1 \mathrm{H}, 3-\mathrm{Ha}), 3.79(\mathrm{~s}, 3 \mathrm{H}$, $\left.\mathrm{OCH}_{3}\right), 4.55(\mathrm{~d}, J=8.2 \mathrm{~Hz}, 1 \mathrm{H}, 11 \mathrm{~b}-\mathrm{H}), 6.19(\mathrm{dd}, J=15.7,9.3 \mathrm{~Hz}, 1$ $\mathrm{H}, \alpha-\mathrm{H}), 6.49(\mathrm{~d}, 1 \mathrm{H}, \mathrm{H}-\beta, J=15.7 \mathrm{~Hz}), 6.82\left(\mathrm{~d}, 2 \mathrm{H}, \mathrm{H}-3^{\prime}, 5^{\prime}, J=\right.$ $8.6 \mathrm{~Hz}$ ), 7.25 (d, $\left.2 \mathrm{H}, \mathrm{H}-2^{\prime}, 6^{\prime}, J=8.6 \mathrm{~Hz}\right), 7.41-7.44(\mathrm{~m}, 2 \mathrm{H}, \mathrm{H}-7, \mathrm{H}-$ 9), 7.67 (ddd, $1 \mathrm{H}, \mathrm{H}-8, J=8.2,7.3,1.4 \mathrm{~Hz}), 8.29$ (dd, $1 \mathrm{H}, \mathrm{H}-10, J=$ 7.9, $1.4 \mathrm{~Hz})$ ppm. ${ }^{13} \mathrm{C}$ NMR $\left(125 \mathrm{MHz}, \mathrm{CDCl}_{3}\right): \delta=24.8\left(\mathrm{NCH}_{3}\right), 32.5$ (C-5), 38.1 (C-11b), $39.0(\mathrm{C}-4), 44.5(\mathrm{C}-3 \mathrm{a}), 55.3\left(\mathrm{OCH}_{3}\right), 112.8(\mathrm{C}-11 \mathrm{a})$, $114.1\left(\mathrm{C}-3^{\prime}, 5^{\prime}\right), 117.7(\mathrm{C}-7), 123.6(\mathrm{C}-\alpha), 123.9$ (C-10a), 125.3 (C-9), $126.4(\mathrm{C}-10), 127.7\left(\mathrm{C}-2^{\prime}, 6^{\prime}\right), 129.0\left(\mathrm{C}-1^{\prime}\right), 132.3(\mathrm{C}-\beta), 133.8(\mathrm{C}-8)$, 155.7 (C-6a), 159.5 (C-4'), 163.6 (C-5a), 175.1 (C-3), 176.0 (C-11), 176.5 (C-1) ppm.

Bisadduct 7c was isolated as a mixture of diastereomers from the reaction of $3 \mathrm{c}(37 \mathrm{mg}, 0.121 \mathrm{mmol})$ with NMM (202 mg, $1.815 \mathrm{mmol})$ in dry DMF $(10 \mu \mathrm{L})$ at $160{ }^{\circ} \mathrm{C}$ in a multimode MV apparatus, and the residue was purified by preparative TLC with ethyl acetate/hexane (4:1) as the eluent. Further purification of the mixture of diastereomers by preparative TLC with dichloromethane/ ethyl acetate (10:2) as the eluent afforded diastereomer I. Diastereomer II was characterized by ${ }^{1} \mathrm{H}$ and ${ }^{13} \mathrm{C}$ NMR spectroscopy with a mixture with diastereomer I (enriched in diastereomer II).

rel-(3aR,4R,5aR,5bR,8aR,14bS, 14cS)-4-(4-Methoxyphenyl)-2,7dimethyl-3a,4,5,5a,5b,8a, 14b, 14c-octahydro-1 $\mathrm{H}$-chromeno[3,2-e]isoindolo[4,5-g]isoindole-1,3,6,8,9(2H,7H)-pentaone (7c, Diastereomer I): White solid, m.p. $230-232{ }^{\circ} \mathrm{C} .{ }^{1} \mathrm{H}$ NMR $(300 \mathrm{MHz}$, $\left.\mathrm{CDCl}_{3}\right): \delta=1.98-2.11(\mathrm{~m}, 1 \mathrm{H}, 5-\mathrm{H}), 2.25-2.36(\mathrm{~m}, 1 \mathrm{H}, 5 \mathrm{a}-\mathrm{H}), 2.79-$ $2.84(\mathrm{~m}, 1 \mathrm{H}, 5-\mathrm{H}), 2.93,2.94\left(2 \mathrm{~s}, 3 \mathrm{H}, 2-\right.$ and $\left.7-\mathrm{NCH}_{3}\right), 3.24$ (ddd, $J=$ $12.5,4.0,1.2 \mathrm{~Hz}, 1 \mathrm{H}, 14 \mathrm{~b}-\mathrm{H}), 3.36(\mathrm{dd}, J=8.7,4.9 \mathrm{~Hz}, 1 \mathrm{H}, 5 \mathrm{~b}-\mathrm{H})$, 3.49 (dd, $J=9.3,6.2 \mathrm{~Hz}, 1 \mathrm{H}, 3 \mathrm{a}-\mathrm{H}), 3.61-3.69(\mathrm{~m}, 1 \mathrm{H}, 4-\mathrm{H}), 3.82(\mathrm{~s}$, $\left.3 \mathrm{H}, \mathrm{OCH}_{3}\right), 4.14(\mathrm{dd}, J=9.3,4.0 \mathrm{~Hz}, 1 \mathrm{H}, 14 \mathrm{c}-\mathrm{H}), 4.72(\mathrm{dd}, J=8.7$, $1.3 \mathrm{~Hz}, 1 \mathrm{H}, 8 \mathrm{a}-\mathrm{H}), 6.92\left(\mathrm{~d}, J=8.6 \mathrm{~Hz}, 2 \mathrm{H}, 3^{\prime}, 5^{\prime}-\mathrm{H}\right), 7.16(\mathrm{~d}, J=8.6 \mathrm{~Hz}$, $\left.2 \mathrm{H}, 2^{\prime}, 6^{\prime}-\mathrm{H}\right), 7.39(\mathrm{~d}, J=8.3 \mathrm{~Hz}, 1 \mathrm{H}, 13-\mathrm{H}), 7.39-7.44(\mathrm{~m}, 1 \mathrm{H}, 11-$ H), 7.66 (ddd, $J=8.3,7.2,1.7 \mathrm{~Hz}, 1 \mathrm{H}), 8.29(\mathrm{dd}, J=8.0,1.7 \mathrm{~Hz}, 1 \mathrm{H}$, 10-H) ppm. $\left.{ }^{13} \mathrm{C} \mathrm{NMR} \mathrm{(75} \mathrm{MHz,} \mathrm{CDCl} 3\right): \delta=24.8,25.1$ (2- and 7- $\mathrm{NCH}_{3}$ ), 25.5 (C-5), 31.6 (C-5a), 33.7 (C-14b), 37.0 (C-4), 39.3 (C-8a), 40.3 (C$14 \mathrm{C}), 43.3(\mathrm{C}-5 \mathrm{~b}), 45.7(\mathrm{C}-3 \mathrm{a}), 55.2\left(\mathrm{OCH}_{3}\right), 113.7\left(\mathrm{C}-8 \mathrm{~b}\right.$ and $\left.\mathrm{C}-3^{\prime}, 5^{\prime}\right)$, 117.5 (C-11), 123.4 (C-9a), 125.4 (C-13), 126.4 (C-10), 128.7 (C-2', $\left.6^{\prime}\right)$, $131.4\left(\mathrm{C}-1^{\prime}\right), 133.9$ (C-12), 155.2 (C-13a), 158.6 (C-4'), 164.0 (C-14a), 174.7, 177.0 (C-6 and C-8), 175.9, 176.1 (C-1, C-3, and C-9) ppm. ElMS: $m / z(\%)=527(26)[\mathrm{M}+\mathrm{H}]^{+}, 526(100)[\mathrm{M}]^{+*}, 414$ (39), El-HRMS: calcd. for $\mathrm{C}_{30} \mathrm{H}_{26} \mathrm{~N}_{2} \mathrm{O}_{7}[\mathrm{M}]^{+}$526.1740; found 526.1754.

rel-(3aR,4R,5aS,5bS,8aS, 14bS,14cS)-4-(4-Methoxyphenyl)-2,7-dimethyl-3a,4,5,5a,5b,8a, 14b, 14c-octahydro-1 $\mathrm{H}$-chromeno[3,2-e]isoindolo[4,5-g]isoindole-1,3,6,8,9(2H,7H)-pentaone (7c, Diastereomer II): ${ }^{1} \mathrm{H}$ NMR $\left(500 \mathrm{MHz}_{1} \mathrm{CDCl}_{3}\right): \delta=2.17-2.20(\mathrm{~m}, 1 \mathrm{H}$, 5-H), 2.89-2.94 (m, $1 \mathrm{H}, 5 \mathrm{a}-\mathrm{H}), 2.89,2.93\left(2 \mathrm{~s}, 3 \mathrm{H}, 2-\right.$ and 7- $\left.\mathrm{NCH}_{3}\right)$, $3.30(\mathrm{t}, J=8.3 \mathrm{~Hz}, 1 \mathrm{H}, 5 \mathrm{~b}-\mathrm{H}), 3.41-3.52(\mathrm{~m}, 3 \mathrm{H}, 5-\mathrm{H}, 4-\mathrm{H}, 14 \mathrm{~b}-\mathrm{H})$, 3.55 (dd, J = 7.8, 5.9 Hz, $1 \mathrm{H}, 3 \mathrm{a}-\mathrm{H}), 3.74-3.79(\mathrm{~m}, 1 \mathrm{H}, 14 \mathrm{c}-\mathrm{H}), 3.83$ $\left(\mathrm{s}, 3 \mathrm{H}, \mathrm{OCH}_{3}\right), 4.64(\mathrm{dd}, J=8.9,1.2 \mathrm{~Hz}, 1 \mathrm{H}, 8 \mathrm{a}-\mathrm{H}), 6.94(\mathrm{~d}, J=8.8 \mathrm{~Hz}$, $\left.2 \mathrm{H}, 3^{\prime}, 5^{\prime}-\mathrm{H}\right), 7.21\left(\mathrm{~d}, J=8.8 \mathrm{~Hz}, 2 \mathrm{H}, 2^{\prime}, 6^{\prime}-\mathrm{H}\right), 7.35(\mathrm{~d}, J=7.9 \mathrm{~Hz}, 1$ $\mathrm{H}, 13-\mathrm{H}), 7.39-7.44(\mathrm{~m}, 1 \mathrm{H}, 11-\mathrm{H}), 7.62-7.70(\mathrm{~m}, 1 \mathrm{H}, 12-\mathrm{H}), 8.28$ (dd, $J=8.0,1.3 \mathrm{~Hz}, 1 \mathrm{H}, 10-\mathrm{H}) \mathrm{ppm} .{ }^{13} \mathrm{C}$ NMR $\left(125 \mathrm{MHz}_{1} \mathrm{CDCl}_{3}\right): \delta=23.8$ 
(C-5), 25.1, 25.3 (2- and 7- $\mathrm{NCH}_{3}$ ), 31.7 (C-5a), 35.5 (C-3a), 38.3 (C-8a), 38.8 (C-4), 39.3 (C-5b), 40.7 (C-14c), 45.6 (C-14b), $55.2\left(\mathrm{OCH}_{3}\right), 113.7$ $\left(\mathrm{C}-3^{\prime}, 5^{\prime}\right), 114.8$ (C-8b), 117.2 (C-11), 123.5 (C-9a), 125.2 (C-13), 126.6 (C-10), 128.8 (C-2',6'), 131.9 (C-1'), 133.9 (C-12), 155.4 (C-13a), 158.6 (C-4'), 161.6 (C-14a), 174.0, 177.6 (C-6 and C-8), 175.8, 175.9, 176.2 (C-1, C-3, and C-9) ppm.

4-(4-Methoxyphenyl)-7-(4-oxo-4H-chromen-2-yl)-2-phenyl3a,4,5,7a-tetrahydro-1H-isoindole-1,3(2H)-dione (8): $\mathrm{N}$-Phenylmaleimide $(62.8 \mathrm{mg}, 0.363 \mathrm{mmol}), \mathrm{Sc}(\mathrm{OTf})_{3}(59.5 \mathrm{mg}, 0.121 \mathrm{mmol})$, and $3 \mathrm{c}(0.121 \mathrm{mmol})$ were mixed in a closed vessel. The resulting mixture was heated at $165{ }^{\circ} \mathrm{C}$ under MV irradiation (monomode apparatus) for $10 \mathrm{~min}$. The residue was dissolved in dichloromethane and purified by preparative TLC with ethyl acetate/hexane (1:1) as the eluent. Yield $38 \mathrm{mg}(66 \%)$, white solid, m.p. $212-214{ }^{\circ} \mathrm{C}$. ${ }^{1} \mathrm{H}$ NMR $\left(300 \mathrm{MHz}, \mathrm{CDCl}_{3}\right): \delta=2.78-2.93(\mathrm{~m}, 2 \mathrm{H}, 5-\mathrm{H}), 3.54-3.74$ (m, $2 \mathrm{H}, 3 \mathrm{a}-\mathrm{H}, 4-\mathrm{H}), 3.75\left(\mathrm{~s}, 3 \mathrm{H}, \mathrm{OCH}_{3}\right), 4.28(\mathrm{dd}, J=7.1,1.7 \mathrm{~Hz}, 1$ $\mathrm{H}, 7 \mathrm{a}-\mathrm{H}), 6.62-6.65(\mathrm{~m}, 1 \mathrm{H}, 6-\mathrm{H}), 6.64\left(\mathrm{~s}, 1 \mathrm{H}, 3^{\prime}-\mathrm{H}\right), 6.81(\mathrm{~d}, J=$ $\left.8.7 \mathrm{~Hz}, 2 \mathrm{H}, 3^{\prime \prime}, 5^{\prime \prime}-\mathrm{H}\right), 7.22$ (d, J= $\left.8.7 \mathrm{~Hz}, 2 \mathrm{H}, 3^{\prime \prime}, 5^{\prime \prime}-\mathrm{H}\right), 7.24-7.30(\mathrm{~m}$, $\left.5 \mathrm{H}, 2^{\prime \prime \prime}, 3^{\prime \prime \prime}, 4^{\prime \prime \prime}, 5^{\prime \prime \prime}, 6^{\prime \prime \prime}-\mathrm{H}\right), 7.39$ (ddd, $\left.J=7.9,7.1,1.0 \mathrm{~Hz}, 1 \mathrm{H}, 6^{\prime}-\mathrm{H}\right)$, 7.47 (dd, $J=8.6,1.0 \mathrm{~Hz}, 1 \mathrm{H}, 8^{\prime}-\mathrm{H}$ ), 7.67 (ddd, $J=8.6,7.1,1.7 \mathrm{~Hz}, 1$ $\left.\mathrm{H}, 7^{\prime}-\mathrm{H}\right), 8.20$ (dd, $\left.J=7.9,1.7 \mathrm{~Hz}, 1 \mathrm{H}, 5^{\prime}-\mathrm{H}\right) \mathrm{ppm} .{ }^{13} \mathrm{C}$ NMR $(75 \mathrm{MHz}$, $\left.\mathrm{CDCl}_{3}\right): \delta=30.0(\mathrm{C}-5), 37.2(\mathrm{C}-4), 39.9(\mathrm{C}-7 \mathrm{a}), 44.8(\mathrm{C}-3 \mathrm{a}), 55.3\left(\mathrm{OCH}_{3}\right)$, $108.9\left(\mathrm{C}-3^{\prime}\right), 114.2\left(\mathrm{C}-3^{\prime \prime}, 5^{\prime \prime}\right), 117.9\left(\mathrm{C}-8^{\prime}\right), 124.0\left(\mathrm{C}-4^{\prime} \mathrm{a}\right), 125.1\left(\mathrm{C}-6^{\prime}\right)$, 125.7 (C-5'), 126.2 (C-2"' (6 $\left.^{\prime \prime \prime}\right), 126.5$ (C-6), 128.5 (C-7), 128.8 $\left(C-3^{\prime \prime \prime}, 5^{\prime \prime \prime}\right), 129.5\left(C-2^{\prime \prime}, 6^{\prime \prime}\right), 131.0\left(C-1^{\prime \prime \prime}\right), 131.3\left(C-1^{\prime \prime}\right), 133.8$ (C-7'), 135.8 (C-4"'), 156.0 (C-8'a), $159.2\left(\mathrm{C}-4^{\prime \prime}\right), 162.3$ (C-2'), $173.0(\mathrm{C}-1)$, $175.6(\mathrm{C}-3), 178.4\left(\mathrm{C}-4^{\prime}\right)$ ppm. El-MS: $m / z(\%)=478(23)[\mathrm{M}+\mathrm{H}]^{+}$, 477 (81) [M] ${ }^{+*}, 474$ (100), 473 (29), 445 (36), 444 (45), 305 (23). ElHRMS: calcd. for $\mathrm{C}_{30} \mathrm{H}_{23} \mathrm{NO}_{5}[\mathrm{M}]^{+} 477.1576$; found 477.1590 .

Dialkyl 4'-Methoxy-4-(4-oxo-4H-chromen-2-yl)-[1,1'-biphenyl]2,3-dicarboxylates 9a and 9b: Dimethyl acetylenedicarboxylate (45 $\mu \mathrm{L}, 0.363 \mathrm{mmol})$ or diethyl acetylenedicarboxylate $(58 \mu \mathrm{L}$, $0.363 \mathrm{mmol}$ ) and chromone $3 \mathrm{c}(37 \mathrm{mg}, 0.121 \mathrm{mmol})$ were mixed in a closed vessel. The resulting mixture was heated at $165^{\circ} \mathrm{C}$ under MV irradiation (monomode apparatus) for $15 \mathrm{~min}$. The residue was dissolved in dichloromethane and purified by preparative TLC with ethyl acetate/hexane (1:1) as the eluent.

Dimethyl 4'-Methoxy-4-(4-oxo-4H-chromen-2-yl)-[1,1'-biphenyl]-2,3-dicarboxylate (9a): Yield $16 \mathrm{mg}$ (30\%), yellow solid, m.p. $226-227{ }^{\circ} \mathrm{C}$. ${ }^{1} \mathrm{H}$ NMR $\left(300 \mathrm{MHz}, \mathrm{CDCl}_{3}\right): \delta=3.69,3.76(2 \times \mathrm{s}$, $\left.2 \times 3 \mathrm{H}, 2,3-\mathrm{CO}_{2} \mathrm{CH}_{3}\right), 3.86\left(\mathrm{~s}, 3 \mathrm{H}, 4^{\prime \prime}-\mathrm{OCH}_{3}\right), 6.64\left(\mathrm{~s}, 1 \mathrm{H}, 3^{\prime}-\mathrm{H}\right), 6.97$ (d, J = 8.7 Hz, $\left.2 \mathrm{H}, 3^{\prime \prime}, 5^{\prime \prime}-\mathrm{H}\right), 7.31$ (d, J= $\left.8.7 \mathrm{~Hz}, 2 \mathrm{H}, 2^{\prime \prime}, 6^{\prime \prime}-\mathrm{H}\right), 7.42$ (d, J = 8.1 Hz, $\left.1 \mathrm{H}, 8^{\prime}-\mathrm{H}\right), 7.45\left(\mathrm{td}, J=7.7,1.0 \mathrm{~Hz}, 1 \mathrm{H}, 6^{\prime}-\mathrm{H}\right), 7.60(\mathrm{~d}$, $J=8.1 \mathrm{~Hz}, 1 \mathrm{H}, 6-\mathrm{H}), 7.67-7.73\left(\mathrm{~m}, 1 \mathrm{H}, 7^{\prime}-\mathrm{H}\right), 7.74(\mathrm{~d}, J=8.1 \mathrm{~Hz}, 1$ $\mathrm{H}, 5-\mathrm{H}), 8.25$ (dd, $\left.J=8.1,1.5 \mathrm{~Hz}, 1 \mathrm{H}, 5^{\prime}-\mathrm{H}\right) \mathrm{ppm} .{ }^{13} \mathrm{C}$ NMR $(75 \mathrm{MHz}$, $\left.\mathrm{CDCl}_{3}\right): \delta=52.7,53.1\left(2,3-\mathrm{CO}_{2} \mathrm{CH}_{3}\right), 55.3\left(4^{\prime \prime}-\mathrm{OCH}_{3}\right), 110.9\left(\mathrm{C}-3^{\prime}\right)$, $114.1\left(\mathrm{C}-3^{\prime \prime}, 5^{\prime \prime}\right), 117.7\left(\mathrm{C}-8^{\prime}\right), 123.8$ (C-4'a), $125.6\left(\mathrm{C}-6^{\prime}\right), 125.9\left(\mathrm{C}-5^{\prime}\right)$, $129.4\left(\mathrm{C}-2^{\prime \prime}, 6^{\prime \prime}\right), 130.3$ (C-5), 130.4 (C-4), $131.0\left(\mathrm{C}-1^{\prime \prime}\right), 131.4$ (C-3), 132.4 (C-6), 133.3 (C-2), 134.1 (C-7'), 143.2 (C-1), 156.3 (C-8'a), 159.8 $\left(\mathrm{C}-4^{\prime \prime}\right), 163.6\left(\mathrm{C}-2^{\prime}\right), 167.6,168.2\left(2,3-\mathrm{CO}_{2} \mathrm{CH}_{3}\right), 178.0\left(\mathrm{C}-4^{\prime}\right)$ ppm. ElMS: $m / z(\%)=445(20)[\mathrm{M}+\mathrm{H}]^{+}, 444(100)[\mathrm{M}]^{+*}, 413$ (36). El-HRMS: calcd. for $\mathrm{C}_{26} \mathrm{H}_{20} \mathrm{O}_{7}[\mathrm{M}]^{+}$444.1209; found 444.1214.

Diethyl 4'-Methoxy-4-(4-oxo-4H-chromen-2-yl)-[1,1'-biphenyl]2,3-dicarboxylate (9b): Yield 20 mg (35\%), yellow solid, m.p. 170$172{ }^{\circ} \mathrm{C} .{ }^{1} \mathrm{H}$ NMR $\left(300 \mathrm{MHz}, \mathrm{CDCl}_{3}\right): \delta=1.078,1.083(2 \times 3 \mathrm{t}, J=7.2 \mathrm{~Hz}$, $2 \times 3 \mathrm{H}, 2-$ and $\left.3-\mathrm{CO}_{2} \mathrm{CH}_{2} \mathrm{CH}_{3}\right), 3.86\left(\mathrm{~s}, 3 \mathrm{H}, \mathrm{OCH}_{3}\right), 4.14(\mathrm{q}, J=7.2 \mathrm{~Hz}$, $\left.2 \mathrm{H}, 2-\mathrm{CO}_{2} \mathrm{CH}_{2} \mathrm{CH}_{3}\right), 4.21\left(\mathrm{q}, J=7.2 \mathrm{~Hz}, 2 \mathrm{H}, 3-\mathrm{CO}_{2} \mathrm{CH}_{2} \mathrm{CH}_{3}\right), 6.63$ (s, $\left.1 \mathrm{H}, 3^{\prime}-\mathrm{H}\right), 6.96\left(\mathrm{~d}, J=8.7 \mathrm{~Hz}, 2 \mathrm{H}, 3^{\prime \prime}, 5^{\prime \prime}-\mathrm{H}\right), 7.32(\mathrm{~d}, J=8.7 \mathrm{~Hz}, 2 \mathrm{H}$, $\left.2^{\prime \prime}, 6^{\prime \prime}-\mathrm{H}\right), 7.42\left(\mathrm{~d}, J=8.4 \mathrm{~Hz}, 1 \mathrm{H}, 8^{\prime}-\mathrm{H}\right), 7.45$ (ddd, $J=8.0,7.2,1.2 \mathrm{~Hz}$, $\left.1 \mathrm{H}, 6^{\prime}-\mathrm{H}\right), 7.58(\mathrm{~d}, J=8.0 \mathrm{~Hz}, 1 \mathrm{H}, 6-\mathrm{H}), 7.70(\mathrm{ddd}, J=8.4,7.2,1.7 \mathrm{~Hz}$, $\left.1 \mathrm{H}, 7^{\prime}-\mathrm{H}\right), 7.72(\mathrm{~d}, J=8.0 \mathrm{~Hz}, 1 \mathrm{H}, 5-\mathrm{H}), 8.26(\mathrm{dd}, J=8.0,1.7 \mathrm{~Hz}, 1$ $\left.\mathrm{H}, 5^{\prime}-\mathrm{H}\right) \mathrm{ppm} .{ }^{13} \mathrm{C}$ NMR $\left(75 \mathrm{MHz}, \mathrm{CDCl}_{3}\right): \delta=13.7,13.8(2,3-$
$\left.\mathrm{CO}_{2} \mathrm{CH}_{2} \mathrm{CH}_{3}\right), 55.4\left(\mathrm{OCH}_{3}\right), 61.8\left(2-\mathrm{CO}_{2} \mathrm{CH}_{2} \mathrm{CH}_{3}\right), 62.3\left(3-\mathrm{CO}_{2} \mathrm{CH}_{2} \mathrm{CH}_{3}\right)$, $111.0\left(\mathrm{C}-3^{\prime}\right), 114.0\left(\mathrm{C}-3^{\prime \prime}, 5^{\prime \prime}\right), 117.8\left(\mathrm{C}-8^{\prime}\right), 123.8\left(\mathrm{C}-4^{\prime} \mathrm{a}\right), 125.5\left(\mathrm{C}-6^{\prime}\right)$, 125.9 (C-5'), $129.5\left(\mathrm{C}-2^{\prime \prime}, 6^{\prime \prime}\right), 130.2$ (C-5), 130.5 (C-4), $131.2\left(\mathrm{C}-1^{\prime \prime}\right)$, 131.5 (C-3), 132.3 (C-6), 133.8 (C-2), 134.1 (C-7'), 143.2 (C-1), 156.3 $\left(\mathrm{C}-8^{\prime} \mathrm{a}\right), 159.8\left(4^{\prime \prime}\right), 163.9\left(\mathrm{C}-2^{\prime}\right), 167.0\left(3-\mathrm{CO}_{2} \mathrm{CH}_{2} \mathrm{CH}_{3}\right), 167.7$ (2$\left.\mathrm{CO}_{2} \mathrm{CH}_{2} \mathrm{CH}_{3}\right), 178.0\left(\mathrm{C}-4^{\prime}\right)$ ppm. El-MS: $m / z(\%)=473(20)[\mathrm{M}+\mathrm{H}]^{+}$, 472 (100) [M] ${ }^{+*}, 399$ (91), 327 (21). El-HRMS: calcd. for $\mathrm{C}_{28} \mathrm{H}_{24} \mathrm{O}_{7}[\mathrm{MM}]^{+}$ 472.1522; found 472.1524 .

Dialkyl 3-(4-Methoxyphenyl)-6-(4-oxo-4H-chromen-2-yl)-3,6-dihydropyridazine-1,2-dicarboxylates 10a and 10b: Diethyl azodicarboxylate toluene solution $(0.14 \mathrm{~mL}, 0.363 \mathrm{mmol})$ or diisopropyl azodicarboxylate $(71 \mu \mathrm{L}, 0.363 \mathrm{mmol}$ ) and chromone $3 c(37 \mathrm{mg}$, $0.121 \mathrm{mmol}$ ) were mixed in a closed vessel. The resulting mixture was heated at $165{ }^{\circ} \mathrm{C}$ under MV irradiation (monomode apparatus) for 15 or $10 \mathrm{~min}$, respectively. The residue was dissolved in dichloromethane and purified by preparative TLC with ethyl acetate/hexane (1:1) as the eluent.

Diethyl 3-(4-Methoxyphenyl)-6-(4-oxo-4H-chromen-2-yl)-3,6-dihydropyridazine-1,2-dicarboxylate (10a): Yield $13 \mathrm{mg}(22 \%)$, colorless oil. ${ }^{1} \mathrm{H}$ NMR $\left(300 \mathrm{MHz}, \mathrm{CDCl}_{3}\right): \delta=0.71-0.77(\mathrm{~m}, 6 \mathrm{H}, 1,2-$ $\left.\mathrm{CO}_{2} \mathrm{CH}_{2} \mathrm{CH}_{3}\right), 3.56-3.95\left(\mathrm{~m}, 4 \mathrm{H}, 1,2-\mathrm{CO}_{2} \mathrm{CH}_{2} \mathrm{CH}_{3}\right), 3.80\left(\mathrm{~s}, 3 \mathrm{H}, \mathrm{OCH}_{3}\right)$, 5.87-5.90 (m, $2 \mathrm{H}, 3-\mathrm{H}, 6-\mathrm{H}), 6.21-6.24(\mathrm{~m}, 1 \mathrm{H}, 4-\mathrm{H}), 6.28-6.31(\mathrm{~m}$, $1 \mathrm{H}, 5-\mathrm{H}), 6.45\left(\mathrm{~s}, 1 \mathrm{H}, 3^{\prime}-\mathrm{H}\right), 6.86\left(\mathrm{~d}, J=8.6 \mathrm{~Hz}, 2 \mathrm{H}, 3^{\prime \prime}, 5^{\prime \prime}-\mathrm{H}\right), 7.32$ (d, J = 8.6 Hz, $2 \mathrm{H}, 2^{\prime \prime}, 6^{\prime \prime}-\mathrm{H}$ ), 7.40 (ddd, J=8.0, 7.1, 1.1 Hz, $1 \mathrm{H}, 6^{\prime}-$ H), $7.49\left(\mathrm{~d}, J=8.3 \mathrm{~Hz}, 1 \mathrm{H}, 8^{\prime}-\mathrm{H}\right), 7.67$ (ddd, $J=8.3,7.1,1.7 \mathrm{~Hz}, 1 \mathrm{H}$, $\left.7^{\prime}-\mathrm{H}\right), 8.18$ (dd, $\left.J=8.0,1.7 \mathrm{~Hz}, 1 \mathrm{H}, 5^{\prime}-\mathrm{H}\right) \mathrm{ppm} .{ }^{13} \mathrm{C}$ NMR $(75 \mathrm{MHz}$, $\left.\mathrm{CDCl}_{3}\right): \delta=13.8,13.9\left(1,2-\mathrm{CO}_{2} \mathrm{CH}_{2} \mathrm{CH}_{3}\right), 53.8(\mathrm{C}-6), 54.8(\mathrm{C}-3), 55.4$ $\left(\mathrm{OCH}_{3}\right), 62.3,62.5\left(1,2-\mathrm{CO}_{2} \mathrm{CH}_{2} \mathrm{CH}_{3}\right), 111.1\left(\mathrm{C}-3^{\prime}\right), 113.8\left(\mathrm{C}-3^{\prime \prime}, 5^{\prime \prime}\right)$, $118.2\left(\mathrm{C}-8^{\prime}\right), 121.9$ (C-4), 123.8 (C-4'a), 125.3 (C-6'), 125.7 (C-5'), 129.4 $\left(\mathrm{C}-1^{\prime \prime}\right), 129.5(\mathrm{C}-5), 129.8\left(\mathrm{C}-2^{\prime \prime}, 6^{\prime \prime}\right), 133.9\left(\mathrm{C}-7^{\prime}\right), 154.9,155.5(1,2-$ $\left.\mathrm{CO}_{2} \mathrm{CH}_{2} \mathrm{CH}_{3}\right), 156.4$ (C-8'a), $159.7\left(\mathrm{C}-4^{\prime \prime}\right), 163.8\left(\mathrm{C}-2^{\prime}\right), 178.2\left(\mathrm{C}-4^{\prime}\right)$ ppm. El-MS: $m / z(\%)=478$ (17) [M] ${ }^{+*}, 405$ (54), 390 (33), 389 (86), 318 (75), 317 (54), 303 (100), 197 (69). El-HRMS: calcd. for $\mathrm{C}_{26} \mathrm{H}_{26} \mathrm{~N}_{2} \mathrm{O}_{7}[\mathrm{M}]^{+}$478.1740; found 478.1745 .

Diisopropyl 3-(4-Methoxyphenyl)-6-(4-oxo-4H-chromen-2-yl)3,6-dihydropyridazine-1,2-dicarboxylate (10b): Yield $35 \mathrm{mg}$ (57\%), yellow oil. ${ }^{1} \mathrm{H}$ NMR $\left(300 \mathrm{MHz} \mathrm{CDCl}_{3}\right): \delta=0.530,0.97(2 \times \mathrm{d}$, $\left.J=6.2 \mathrm{~Hz}, 2 \times 3 \mathrm{H}, 4^{\prime \prime \prime \prime}, 5^{\prime \prime \prime \prime}-\mathrm{CH}_{3}\right), 0.531,1.03(2 \times \mathrm{d}, J=6.2 \mathrm{~Hz}, 2 \times 3$ $\left.\mathrm{H}, 4^{\prime \prime \prime}, 5^{\prime \prime \prime}-\mathrm{CH}_{3}\right), 3.79\left(\mathrm{~s}, 3 \mathrm{H}, 4^{\prime \prime}-\mathrm{OCH}_{3}\right), 4.60$ (sept, J = $6.3 \mathrm{~Hz}, 1 \mathrm{H}$, $\left.3^{\prime \prime \prime}-\mathrm{H}\right), 4.71$ (sept, J = 6.3 Hz, $\left.1 \mathrm{H}, 3^{\prime \prime \prime \prime}-\mathrm{H}\right), 5.87-5.92(\mathrm{~m}, 2 \mathrm{H}, 3-\mathrm{H}, 6-$ H), 6.19-6.32 (m, $2 \mathrm{H}, 4-\mathrm{H}, 5-\mathrm{H}), 6.86\left(\mathrm{~d}, J=8.7 \mathrm{~Hz}, 2 \mathrm{H}, 3^{\prime \prime}, 5^{\prime \prime}-\mathrm{H}\right)$, 7.33 (d, $\left.J=8.7 \mathrm{~Hz}, 2 \mathrm{H}, 2^{\prime \prime}, 6^{\prime \prime}-\mathrm{H}\right), 7.40$ (ddd, $J=8.0,7.1,1.0 \mathrm{~Hz}, 1 \mathrm{H}$, $\left.6^{\prime}-\mathrm{H}\right), 7.50\left(\mathrm{dd}, J=8.6,1.0 \mathrm{~Hz}, 1 \mathrm{H}, 8^{\prime}-\mathrm{H}\right), 7.67$ (ddd, $J=8.6,7.1$, $\left.1.7 \mathrm{~Hz}, 1 \mathrm{H}, 7^{\prime}-\mathrm{H}\right), 8.18\left(\mathrm{dd}, J=8.0,1.7 \mathrm{~Hz}, 1 \mathrm{H}, 5^{\prime}-\mathrm{H}\right) \mathrm{ppm} .{ }^{13} \mathrm{C} \mathrm{NMR}$ $\left(75 \mathrm{MHz}, \mathrm{CDCl}_{3}\right): \delta=20.9,21.2\left(5^{\prime \prime \prime \prime}-\right.$ and $\left.4^{\prime \prime \prime \prime}-\mathrm{CH}_{3}\right), 21.81,21.83\left(5^{\prime \prime \prime}-\right.$ and $\left.4^{\prime \prime \prime}-\mathrm{CH}_{3}\right), 53.5(\mathrm{C}-6), 54.5(\mathrm{C}-6), 55.4\left(4^{\prime \prime}-\mathrm{OCH}_{3}\right), 69.9\left(\mathrm{C}-3^{\prime \prime \prime \prime}\right), 70.3$ $\left(\mathrm{C}-3^{\prime \prime \prime}\right), 111.2\left(\mathrm{C}-3^{\prime}\right), 113.8\left(\mathrm{C}-3^{\prime \prime}, 5^{\prime \prime}\right), 118.3\left(\mathrm{C}-8^{\prime}\right), 121.8$ (C-4 or C-5), 123.9 (C-4'a), 125.3 (C-6'), 125.6 (C-5'), 129.6, 129.7 (C-1 and C-4 or C-5), $129.8\left(C-2^{\prime \prime}, 6^{\prime \prime}\right), 133.9\left(C-7^{\prime}\right), 154.4\left(C-1^{\prime \prime \prime \prime}\right), 154.8\left(C-1^{\prime \prime \prime}\right), 156.4$ (C-8'a), 159.7 (C-4"'), 163.9 (C-2'), 178.2 (C-4') ppm. El-MS: m/z (\%) = 506 (5) [M] ${ }^{+*}, 420$ (67), 403 (28), 333 (42), 318 (71), 317 (100), 316 (21), 305 (89), 303 (63), 302 (34), 197 (39). El-HRMS: calcd. for $\mathrm{C}_{28} \mathrm{H}_{30} \mathrm{~N}_{2} \mathrm{O}_{7}[\mathrm{M}]^{+}$506.2053; found 506.2061.

4-[1,2-Bis(ethoxycarbonyl)hydrazinyl]-3-(4-methoxyphenyl)-6(4-oxo-4H-chromen-2-yl)-3,4-dihydropyridazine-1,2-dicarboxylate (11): Diethyl azodicarboxylate solution $(0.14 \mathrm{~mL}, 0.363 \mathrm{mmol})$ and $3 c$ (37 mg, $0.121 \mathrm{mmol}$ ) were mixed in a closed vessel. The resulting mixture was heated at $130^{\circ} \mathrm{C}$ under MV irradiation (monomode apparatus) for $10 \mathrm{~min}$. The residue was dissolved in dichloromethane and purified by preparative TLC with ethyl acetate/hexane $(1: 1)$ as the eluent. Yield $24 \mathrm{mg}(30 \%)$, yellow solid, m.p. $110-112^{\circ} \mathrm{C}$. ${ }^{1} \mathrm{H}$ NMR $\left(500 \mathrm{MHz},\left[\mathrm{D}_{6}\right] \mathrm{DMSO}, 80^{\circ} \mathrm{C}\right): \delta=0.81,1.10(2 \times \mathrm{t}, J=7.0 \mathrm{~Hz}$, 
$\left.2 \times 3 \mathrm{H}, 2 \times \mathrm{CH}_{3}\right), 1.14-1.17\left(\mathrm{~m}, 3 \mathrm{H}, \mathrm{CH}_{3}\right), 1.25(\mathrm{t}, J=7.0 \mathrm{~Hz}, 3 \mathrm{H}$, $\left.\mathrm{CH}_{3}\right), 3.66-3.83\left(\mathrm{~m}, 2 \mathrm{H}, \mathrm{CH}_{2}\right), 3.75\left(\mathrm{~s}, 3 \mathrm{H}, \mathrm{OCH}_{3}\right), 4.01-4.09(\mathrm{~m}, 4 \mathrm{H}$, $\left.\mathrm{CH}_{2}\right), 4.13-4.20\left(\mathrm{~m}, 2 \mathrm{H}, \mathrm{CH}_{2}\right), 5.07$ (br s, $\left.1 \mathrm{H}, 3-\mathrm{H}\right), 5.70$ (br s, $1 \mathrm{H}, 4-$ H), $6.49\left(\mathrm{~s}, 1 \mathrm{H}, 3^{\prime}-\mathrm{H}\right), 6.53(\mathrm{br} \mathrm{s}, 1 \mathrm{H}, 5-\mathrm{H}), 6.92(\mathrm{~d}, J=8.5 \mathrm{~Hz}, 2 \mathrm{H}$, $\left.3^{\prime \prime}, 5^{\prime \prime}-\mathrm{H}\right), 7.27$ (d, J = 8.5 Hz, $\left.2 \mathrm{H}, 2^{\prime \prime}, 6^{\prime \prime}-\mathrm{H}\right), 7.50$ (ddd, J = 8.0, 7.2, $1.0 \mathrm{~Hz}, 1 \mathrm{H}, 6^{\prime}-\mathrm{H}$ ), 7.61 (dd, $\left.J=8.0,1.0 \mathrm{~Hz}, 1 \mathrm{H}, 8^{\prime}-\mathrm{H}\right), 7.82$ (ddd, $J=$ 8.6, 7.2, $1.7 \mathrm{~Hz}, 1 \mathrm{H}, 7^{\prime}-\mathrm{H}$ ), 8.05 (dd, $\left.J=8.0,1.7 \mathrm{~Hz}, 1 \mathrm{H}, 5^{\prime}-\mathrm{H}\right), 9.07$ (br s, $1 \mathrm{H}, \mathrm{NH}$ ) ppm. ${ }^{13} \mathrm{C}$ NMR $\left(125 \mathrm{MHz},\left[\mathrm{D}_{6}\right] \mathrm{DMSO}, 80^{\circ} \mathrm{C}\right): \delta=13.2$ $\left(\mathrm{CH}_{3}\right), 13.7\left(\mathrm{CH}_{3}\right), 13.81\left(\mathrm{CH}_{3}\right), 13.83\left(\mathrm{CH}_{3}\right), 54.9\left(\mathrm{OCH}_{3}\right.$ and $\left.\mathrm{C}-3\right), 60.7$ $\left(\mathrm{CH}_{2}\right), 61.8\left(\mathrm{CH}_{2}\right), 62.0\left(\mathrm{CH}_{2}\right), 62.2\left(\mathrm{CH}_{2}\right.$ and $\left.\mathrm{C}-4\right), 107.9\left(\mathrm{C}-3^{\prime}\right), 113.7$ $\left(\mathrm{C}-3^{\prime \prime}, 5^{\prime \prime}\right), 117.8\left(\mathrm{C}-8^{\prime}\right), 121.2(\mathrm{C}-5), 123.1\left(\mathrm{C}-4^{\prime} \mathrm{a}\right), 124.5\left(\mathrm{C}-5^{\prime}\right), 125.3$ $\left(\mathrm{C}-6^{\prime}\right), 128.5\left(\mathrm{C}-2^{\prime \prime}, 6^{\prime \prime}\right), 129.4\left(\mathrm{C}-1^{\prime \prime}\right), 134.1\left(\mathrm{C}-7^{\prime}\right), 136.0(\mathrm{C}-6), 152.4$ $\left(\mathrm{CO}_{2}\right), 153.3\left(\mathrm{CO}_{2}\right), 154.3\left(\mathrm{CO}_{2}\right), 154.4\left(\mathrm{CO}_{2}\right), 155.1$

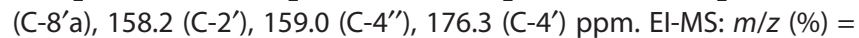
652 (1) [M] ${ }^{+*}, 405$ (96), 372 (74), 359 (50), 331 (96), 225 (77), 208 (100). El-HRMS: calcd. for $\mathrm{C}_{32} \mathrm{H}_{36} \mathrm{~N}_{4} \mathrm{O}_{11}[\mathrm{M}]^{+} 652.2381$; found 652.2386 .

General Procedure for the Synthesis of 4-(4-0xo-4H-chromen-2yl)-7-arylisoindoline-1,3-diones 12a-12e and 14: DDQ (65.4 mg, $0.288 \mathrm{mmol}$ ) was added to a solution of the appropriate adduct 5a-5e and $8(0.072 \mathrm{mmol})$ in 1,2,4-TCB $(0.5 \mathrm{~mL})$. The mixture was heated at $165{ }^{\circ} \mathrm{C}$ under MV irradiation (monomode apparatus) for $25 \mathrm{~min}$. The residue was treated with a sodium hydrogen carbonate aqueous solution $(20 \mathrm{~mL})$, and the aqueous layer was extracted with dichloromethane $(3 \times 50 \mathrm{~mL})$. The organic layer was dried with anhydrous sodium sulfate, and the solvent was evaporated to dryness. The residue was purified by preparative TLC with hexane followed by ethyl acetate/hexane (9:7) as the eluent.

2-Methyl-4-(4-oxo-4H-chromen-2-yl)-7-phenylisoindoline-1,3dione (12a): Yield $23 \mathrm{mg}(85 \%)$, white solid, m.p. $243-245{ }^{\circ} \mathrm{C} .{ }^{1} \mathrm{H}$ NMR (300 MHz, $\left.\mathrm{CDCl}_{3}\right): \delta=3.15\left(\mathrm{~s}, 3 \mathrm{H}, \mathrm{NCH}_{3}\right), 6.76\left(\mathrm{~s}, 1 \mathrm{H}, 3^{\prime}-\mathrm{H}\right)$, 7.47 (ddd, $\left.J=8.0,7.0,1.0 \mathrm{~Hz}, 1 \mathrm{H}, 6^{\prime}-\mathrm{H}\right), 7.49-7.59\left(\mathrm{~m}, 6 \mathrm{H}, 2^{\prime \prime}, 3^{\prime \prime}, 4^{\prime \prime}\right.$ ,5",6"-H; 8'-H), 7.73 (ddd, $\left.J=8.5,7.0,1.7 \mathrm{~Hz}, 1 \mathrm{H}, 7^{\prime}-\mathrm{H}\right), 7.77$ (d, $J=$ $8.0 \mathrm{~Hz}, 1 \mathrm{H}, 5-\mathrm{H}), 7.93(\mathrm{~d}, J=8.0 \mathrm{~Hz}, 1 \mathrm{H}, 6-\mathrm{H}), 8.29$ (dd, J = 8.0, $\left.1.7 \mathrm{~Hz}, 1 \mathrm{H}, 5^{\prime}-\mathrm{H}\right)$ ppm. ${ }^{13} \mathrm{C} \mathrm{NMR}\left(75 \mathrm{MHz}, \mathrm{CDCl}_{3}\right): \delta=24.1\left(\mathrm{NCH}_{3}\right)$, $112.7\left(\mathrm{C}-3^{\prime}\right), 118.2\left(\mathrm{C}-8^{\prime}\right), 124.0$ (C-4'a), $125.5\left(\mathrm{C}-6^{\prime}\right), 125.8\left(\mathrm{C}-5^{\prime}\right), 128.2$ $\left(\mathrm{C}-2^{\prime \prime}, 6^{\prime \prime}\right), 129.0$ (C-3a), 129.2 (C-4"), $129.4\left(\mathrm{C}-3^{\prime \prime}, 5^{\prime \prime}\right.$ and C-7), 130.6 (C-7a), 133.9 (C-6), 134.2 (C-7'), 135.5 (C-1"), 136.2 (C-5), 143.1 (C-4), 156.6 (C-8'a), 160.9 (C-2'), 165.9, 166.9 (C-1 and C-3), 178.1 (C-4') ppm. El-MS: $m / z(\%)=382[\mathrm{M}+\mathrm{H}]^{+}(21), 381\left[\mathrm{M}^{+\cdot}(100), 353(23)\right.$, 325 (26). El-HRMS: calcd. for $\mathrm{C}_{24} \mathrm{H}_{15} \mathrm{NO}_{4}[\mathrm{M}]^{+} 381.1001$; found 381.1005 .

4-(4-Chlorophenyl)-2-methyl-7-(4-oxo-4H-chromen-2-yl)isoindoline-1,3-dione (12b): Yield $22 \mathrm{mg}$ (75\%), white solid, m.p. 214-216 ${ }^{\circ} \mathrm{C} .{ }^{1} \mathrm{H}$ NMR (300 MHz, $\left.\mathrm{CDCl}_{3}\right): \delta=3.16\left(\mathrm{~s}, 3 \mathrm{H}, \mathrm{NCH}_{3}\right), 6.75$ (s, $\left.1 \mathrm{H}, 3^{\prime}-\mathrm{H}\right), 7.44-7.55\left(\mathrm{~m}, 6 \mathrm{H}, 6^{\prime}-\mathrm{H}, 8^{\prime}-\mathrm{H}, 2^{\prime \prime}, 6^{\prime \prime}-\mathrm{H}, 3^{\prime \prime} 5^{\prime \prime}-\mathrm{H}\right), 7.73$ (ddd, $\left.J=8.6,7.1,1.7 \mathrm{~Hz}, 1 \mathrm{H}, 7^{\prime}-\mathrm{H}\right), 7.74(\mathrm{~d}, J=8.0 \mathrm{~Hz}, 1 \mathrm{H}, 5-\mathrm{H})$, $7.94(\mathrm{~d}, J=8.0 \mathrm{~Hz}, 1 \mathrm{H}, 6-\mathrm{H}), 8.28\left(\mathrm{dd}, J=8.0,1.7 \mathrm{~Hz}, 1 \mathrm{H}, 5^{\prime}-\mathrm{H}\right)$ ppm. ${ }^{13} \mathrm{C}$ NMR $\left(75 \mathrm{MHz}, \mathrm{CDCl}_{3}\right): \delta=24.2\left(\mathrm{NCH}_{3}\right), 112.8\left(\mathrm{C}-3^{\prime}\right), 118.2$ (C-8'), 124.0 (C-4'a), 125.5 (C-6'), 125.8 (C-5'), $128.5\left(\mathrm{C}-3^{\prime \prime}, 5^{\prime \prime}\right), 129.0$ (C-3a), 129.7 (C-7), 130.6 (C-7a), 130.7 (C-2", ,6"), 133.9 (C-4"), 134.1 $\left(\mathrm{C}-7^{\prime}\right), 134.2(\mathrm{C}-6), 135.6\left(\mathrm{C}-1^{\prime \prime}\right), 136.0(\mathrm{C}-5), 141.7(\mathrm{C}-4), 156.6$ (C-8' a), 160.7 (C-2'), 165.8, 166.8 (C-1 and C-3), 178.0 (C-4') ppm. El-MS: $\mathrm{m} / \mathrm{z}(\%)=417[\mathrm{M}]^{+\cdot}\left({ }^{37} \mathrm{Cl}, 24\right), 415[\mathrm{M}]^{+\cdot}\left({ }^{35} \mathrm{Cl}, 100\right)$. El-HRMS: calcd. for $\mathrm{C}_{24} \mathrm{H}_{14}{ }^{35} \mathrm{CINO}_{4}[\mathrm{M}]^{+}$415.0611; found 415.0624.

4-(4-Methoxyphenyl)-2-methyl-7-(4-oxo-4H-chromen-2-yl)isoindoline-1,3-dione (12c): Yield $27 \mathrm{mg}$ (90\%), yellow solid, m.p. 217-219 ${ }^{\circ} \mathrm{C} .{ }^{1} \mathrm{H}$ NMR (300 MHz, $\left.\mathrm{CDCl}_{3}\right): \delta=3.16\left(\mathrm{~s}, 3 \mathrm{H}, \mathrm{NCH}_{3}\right), 3.90$ $\left(\mathrm{s}, 3 \mathrm{H}, \mathrm{OCH}_{3}\right), 6.75\left(\mathrm{~s}, 1 \mathrm{H}, 3^{\prime}-\mathrm{H}\right), 7.04\left(\mathrm{~d}, J=8.8 \mathrm{~Hz}, 2 \mathrm{H}, 3^{\prime \prime}, 5^{\prime \prime}-\mathrm{H}\right)$, $7.46\left(\mathrm{td}, J=7.7,1.0 \mathrm{~Hz}, 1 \mathrm{H}, 6^{\prime}-\mathrm{H}\right), 7.50-7.52\left(\mathrm{~m}, 1 \mathrm{H}, 8^{\prime}-\mathrm{H}\right), 7.55(\mathrm{~d}$, $\left.J=8.8 \mathrm{~Hz}, 2 \mathrm{H}, 2^{\prime \prime}, 6^{\prime \prime}-\mathrm{H}\right), 7.70-7.76\left(\mathrm{~m}, 1 \mathrm{H}, 7^{\prime}-\mathrm{H}\right), 7.75(\mathrm{~d}, J=8.1 \mathrm{~Hz}$, $1 \mathrm{H}, 5-\mathrm{H}), 7.90(\mathrm{~d}, J=8.1 \mathrm{~Hz}, 1 \mathrm{H}, 6-\mathrm{H}), 8.28(\mathrm{dd}, J=7.7,1.6 \mathrm{~Hz}, 1$
$\left.\mathrm{H}, 5^{\prime}-\mathrm{H}\right) \mathrm{ppm} .{ }^{13} \mathrm{C}$ NMR (75 MHz, $\left.\mathrm{CDCl}_{3}\right): \delta=24.1\left(\mathrm{NCH}_{3}\right), 55.4$ $\left(\mathrm{OCH}_{3}\right), 112.6\left(\mathrm{C}-3^{\prime}\right), 113.7\left(\mathrm{C}-3^{\prime \prime}, 5^{\prime \prime}\right), 118.2\left(\mathrm{C}-8^{\prime}\right), 124.0\left(\mathrm{C}-4^{\prime} \mathrm{a}\right), 125.4$ $\left(\mathrm{C}-6^{\prime}\right), 125.8\left(\mathrm{C}-5^{\prime}\right), 127.7\left(\mathrm{C}-1^{\prime \prime}\right), 128.6(\mathrm{C}-3 \mathrm{a}), 128.8$ (C-7), 130.7 (C7a), 130.9 (C-2",6"), 133.9 (C-6), 134.1 (C-7'), 136.1 (C-5), 142.9 (C-4), 156.6 (C-8'a), 160.5 (C-4"), $161.0\left(\mathrm{C}-2^{\prime}\right), 166.0,167.1$ (C-1 and C-3), $178.1\left(\mathrm{C}-4^{\prime}\right)$ ppm. El-MS: $m / z(\%)=412[\mathrm{M}+\mathrm{H}]^{+}(21), 411[\mathrm{M}]^{+}$ (100). El-HRMS: calcd. for $\mathrm{C}_{25} \mathrm{H}_{17} \mathrm{NO}_{5}[\mathrm{M}]^{+} 411.1107$; found 411.1106 .

2-Methyl-4-(4-oxo-4H-chromen-2-yl)-7-(methylphenyl)isoindoline-1,3-dione (12d): Yield $23 \mathrm{mg}(80 \%)$, white solid, m.p. 221$223{ }^{\circ} \mathrm{C} .{ }^{1} \mathrm{H}$ NMR $\left(300 \mathrm{MHz}, \mathrm{CDCl}_{3}\right): \delta=2.45\left(\mathrm{~s}, 3 \mathrm{H}, \mathrm{CH}_{3}\right), 3.15(\mathrm{~s}, 3$ $\left.\mathrm{H}, \mathrm{NCH}_{3}\right), 6.75\left(\mathrm{~s}, 1 \mathrm{H}, 3^{\prime}-\mathrm{H}\right), 7.32\left(\mathrm{~d}, J=8.0 \mathrm{~Hz}, 2 \mathrm{H}, 3^{\prime \prime}, 5^{\prime \prime}-\mathrm{H}\right), 7.44-$ $7.50\left(\mathrm{~m}, 1 \mathrm{H}, 6^{\prime}-\mathrm{H}\right), 7.48\left(\mathrm{~d}, J=8.0 \mathrm{~Hz}, 2 \mathrm{H}, 2^{\prime \prime}, 6^{\prime \prime}-\mathrm{H}\right), 7.52(\mathrm{dd}, J=$ 8.8, $1.0 \mathrm{~Hz}, 1 \mathrm{H}, 8^{\prime}-\mathrm{H}$ ), 7.73 (ddd, $\left.J=8.8,7.1,1.5 \mathrm{~Hz}, 1 \mathrm{H}, 7^{\prime}-\mathrm{H}\right), 7.75$ $(\mathrm{d}, J=8.0 \mathrm{~Hz}, 1 \mathrm{H}, 5-\mathrm{H}), 7.91(\mathrm{~d}, J=8.0 \mathrm{~Hz}, 1 \mathrm{H}, 6-\mathrm{H}), 8.28(\mathrm{dd}, J=$ 7.9, $\left.1.5 \mathrm{~Hz}, 1 \mathrm{H}, 5^{\prime}-\mathrm{H}\right)$ ppm. ${ }^{13} \mathrm{C} \mathrm{NMR}\left(75 \mathrm{MHz}, \mathrm{CDCl}_{3}\right): \delta=21.4\left(\mathrm{CH}_{3}\right)$, $24.1\left(\mathrm{NCH}_{3}\right), 112.7\left(\mathrm{C}-3^{\prime}\right), 118.2\left(\mathrm{C}-8^{\prime}\right), 124.0\left(\mathrm{C}-4^{\prime} \mathrm{a}\right), 125.5\left(\mathrm{C}-6^{\prime}\right)$, $125.8\left(\mathrm{C}-5^{\prime}\right), 128.9$ (C-3a), $129.0\left(\mathrm{C}-3^{\prime \prime}, 5^{\prime \prime}\right), 129.1$ (C-7), 129.3 $\left(\mathrm{C}-2^{\prime \prime}, 6^{\prime \prime}\right), 130.6(\mathrm{C}-7 \mathrm{a}), 132.6\left(\mathrm{C}-1^{\prime \prime}\right), 133.9(\mathrm{C}-6), 134.1\left(\mathrm{C}-7^{\prime}\right), 136.2$ (C-5), $139.4\left(\mathrm{C}-4^{\prime \prime}\right), 143.2$ (C-4), 156.6 (C-8'a), 161.0 (C-2'), 166.0, 167.0 (C-1 and C-3), 178.1 (C-4') ppm. El-MS: $m / z(\%)=395$ [M] $^{+\cdot}(100)$. ElHRMS: calcd. for $\mathrm{C}_{25} \mathrm{H}_{17} \mathrm{NO}_{4}[\mathrm{M}]^{+}$395.1158; found 395.1157.

2-Methyl-4-(4-nitrophenyl)-7-(4-oxo-4H-chromen-2-yl)isoindoline-1,3-dione (12e): Yield $21 \mathrm{mg}$ (70\%), yellow solid, m.p. 266$269{ }^{\circ} \mathrm{C} .{ }^{1} \mathrm{H}$ NMR $\left(300 \mathrm{MHz}, \mathrm{CDCl}_{3}\right): \delta=3.17\left(\mathrm{~s}, 3 \mathrm{H}, \mathrm{NCH}_{3}\right), 6.78(\mathrm{~s}, 1$ $\left.\mathrm{H}, 3^{\prime}-\mathrm{H}\right), 7.48$ (ddd, $\left.J=8.0,7.1,1.0 \mathrm{~Hz}, 1 \mathrm{H}, 6^{\prime}-\mathrm{H}\right), 7.52(\mathrm{~d}, J=7.0 \mathrm{~Hz}$, $\left.1 \mathrm{H}, 8^{\prime}-\mathrm{H}\right), 7.72-7.78\left(\mathrm{~m}, 1 \mathrm{H}, 7^{\prime}-\mathrm{H}\right), 7.74\left(\mathrm{~d}, J=8.9 \mathrm{~Hz}, 2 \mathrm{H}, 2^{\prime \prime}, 6^{\prime \prime}-\right.$ H), $7.78(\mathrm{~d}, J=8.0 \mathrm{~Hz}, 1 \mathrm{H}, 5-\mathrm{H}), 8.01(\mathrm{~d}, J=8.0 \mathrm{~Hz}, 1 \mathrm{H}, 6-\mathrm{H}), 8.29$ (dd, $\left.J=8.0,1.2 \mathrm{~Hz}, 1 \mathrm{H}, 5^{\prime}-\mathrm{H}\right), 8.38$ (d, $\left.J=8.9 \mathrm{~Hz}, 2 \mathrm{H}, 3^{\prime \prime}, 5^{\prime \prime}-\mathrm{H}\right) \mathrm{ppm}$. ${ }^{13} \mathrm{C}$ NMR $\left(75 \mathrm{MHz}, \mathrm{CDCl}_{3}\right): \delta=24.3\left(\mathrm{NCH}_{3}\right), 113.0\left(\mathrm{C}-3^{\prime}\right), 118.2$ (C-8'), $123.4\left(\mathrm{C}-3^{\prime \prime}, 5^{\prime \prime}\right), 124.0$ (C-4'a), 125.6 (C-6'), 125.9 (C-5'), 129.5 (C-3a), 130.5 (C-2", $\left.6^{\prime \prime}\right), 130.67,130.71$ (C-7 and C-7a), 134.3 (C-7', C6), 135.7 (C-5), 140.1 (C-4), 141.9 (C-1" $), 148.2$ (C-4"), 156.6 (C-8'a), $160.2\left(\mathrm{C}-2^{\prime}\right), 165.5,165.6$ (C-1 and C-3), 177.9 (C-4') ppm. El-MS: m/z $(\%)=426[M]^{+\cdot}(17), 396$ (100). El-HRMS: calcd. for $\mathrm{C}_{24} \mathrm{H}_{14} \mathrm{~N}_{2} \mathrm{O}_{6}[\mathrm{M}]^{+}$ 426.0852 ; found 426.0855 .

4-(4-Methoxyphenyl)-7-(4-oxo-4H-chromen-2-yl)-2-phenylisoindoline-1,3-dione (14): Yield $29 \mathrm{mg}(86 \%)$, white solid, m.p. 271$272{ }^{\circ} \mathrm{C}$. ${ }^{1} \mathrm{H}$ NMR $\left(300 \mathrm{MHz}, \mathrm{CDCl}_{3}\right): \delta=3.88\left(\mathrm{~s}, 3 \mathrm{H}, \mathrm{OCH}_{3}\right), 6.75(\mathrm{~s}, 1$ $\left.\mathrm{H}, 3^{\prime}-\mathrm{H}\right), 7.03\left(\mathrm{~d}, J=8.8 \mathrm{~Hz}, 2 \mathrm{H}, 3^{\prime \prime}, 5^{\prime \prime}-\mathrm{H}\right), 7.35-7.38\left(\mathrm{~m}, 1 \mathrm{H}, 4^{\prime \prime \prime}-\mathrm{H}\right)$, 7.39-7.48 (m, $\left.5 \mathrm{H}, 6^{\prime}-\mathrm{H}, 2^{\prime \prime \prime}, 6^{\prime \prime \prime}-\mathrm{H}, 3^{\prime \prime \prime}, 5^{\prime \prime \prime}-\mathrm{H}\right), 7.50(\mathrm{dd}, J=8.4,0.6 \mathrm{~Hz}$, $\left.1 \mathrm{H}, 8^{\prime}-\mathrm{H}\right), 7.59\left(\mathrm{~d}, J=8.8 \mathrm{~Hz}, 2 \mathrm{H}, 2^{\prime \prime}, 6^{\prime \prime}-\mathrm{H}\right), 7.70(\mathrm{ddd}, J=8.4,7.2$, $\left.1.4 \mathrm{~Hz}, 1 \mathrm{H}, 7^{\prime}-\mathrm{H}\right), 7.84(\mathrm{~d}, J=8.1 \mathrm{~Hz}, 1 \mathrm{H}, 5-\mathrm{H}), 7.96(\mathrm{~d}, J=8.1 \mathrm{~Hz}$, $1 \mathrm{H}, 6-\mathrm{H}), 8.27\left(\mathrm{dd}, J=8.0,1.4 \mathrm{~Hz}, 1 \mathrm{H}, 5^{\prime}-\mathrm{H}\right) \mathrm{ppm} .{ }^{13} \mathrm{C}$ NMR $(75 \mathrm{MHz}$, $\left.\mathrm{CDCl}_{3}\right): \delta=55.4\left(\mathrm{OCH}_{3}\right), 112.7\left(\mathrm{C}-3^{\prime}\right), 113.7\left(\mathrm{C}-3^{\prime \prime}, 5^{\prime \prime}\right), 118.3\left(\mathrm{C}-8^{\prime}\right)$, 124.0 (C-4'a), 125.5 (C-6'), $125.8\left(\mathrm{C}-5^{\prime}\right), 126.7\left(\mathrm{C}-2^{\prime \prime \prime}, 6^{\prime \prime \prime}\right), 127.6$

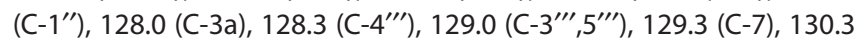
(C-7a), $131.0\left(\mathrm{C}-2^{\prime \prime}, 6^{\prime \prime}\right), 131.3\left(\mathrm{C}-1^{\prime \prime \prime}\right), 134.1\left(\mathrm{C}-7^{\prime}\right), 134.5$ (C-6), 136.6 (C-5), 143.5 (C-4), 156.7 (C-8'a), 160.6 (C-4"), 161.2 (C-2'), 164.9, 166.1 (C-1 and C-3), 178.1 (C-4) ppm. El-MS: $m / z(\%)=477(100), 473[\mathrm{M}]^{+\cdot}$ (95), 444 (54), 222 (77). El-HRMS: calcd. for $\mathrm{C}_{30} \mathrm{H}_{19} \mathrm{NO}_{5}[\mathrm{M}]^{+}$473.1263; found 473.1277 .

4-(4-Methoxyphenyl)-2-methyl-7-(4-oxo-4H-chromen-2-yl)3a,7a-dihydro- $1 \mathrm{H}$-isoindole-1,3(2H)-dione (13c): This compound was obtained as a byproduct in the synthesis of $\mathbf{1 2 c}$ by the same procedure described above but under classical heating conditions with toluene and 1,4-dioxane at $100{ }^{\circ} \mathrm{C}$ and 1,2,4-TCB at $190{ }^{\circ} \mathrm{C}$. After a few hours, the oxidation reaction afforded a mixture of the oxidized product $12 \mathrm{c}$ and the semioxidized product $13 \mathrm{c}$. Yield $15-$ $60 \%$, m.p. $214-216{ }^{\circ} \mathrm{C} .{ }^{1} \mathrm{H}$ NMR $\left(300 \mathrm{MHz}, \mathrm{CDCl}_{3}\right): \delta=2.98(\mathrm{~s}, 3 \mathrm{H}$, $\left.\mathrm{NCH}_{3}\right), 3.85\left(\mathrm{~s}, 3 \mathrm{H}, \mathrm{OCH}_{3}\right), 4.44(\mathrm{~d}, J=11.6 \mathrm{~Hz}, 1 \mathrm{H}, 7 \mathrm{a}-\mathrm{H}), 4.61(\mathrm{~d}$, $J=11.6 \mathrm{~Hz}, 1 \mathrm{H}, 3 \mathrm{a}-\mathrm{H}), 6.45(\mathrm{dd}, J=6.9,1.8 \mathrm{~Hz}, 1 \mathrm{H}, 5-\mathrm{H}), 6.65(\mathrm{~s}, 1$ $\left.\mathrm{H}, 3^{\prime}-\mathrm{H}\right), 6.95\left(\mathrm{~d}, J=8.8 \mathrm{~Hz}, 2 \mathrm{H}, 3^{\prime \prime}, 5^{\prime \prime}-\mathrm{H}\right), 7.14(\mathrm{~d}, J=6.9 \mathrm{~Hz}, 1 \mathrm{H}$, 
6-H), 7.40 (ddd, $J=8.0,7.1,1.0 \mathrm{~Hz}, 1 \mathrm{H}, 6^{\prime}-\mathrm{H}$ ), 7.47 (dd, $J=8.5$, $1.0 \mathrm{~Hz}, 1 \mathrm{H}, 8^{\prime}-\mathrm{H}$ ), $7.54\left(\mathrm{~d}, J=8.8 \mathrm{~Hz}, 2 \mathrm{H}, 2^{\prime \prime}, 6^{\prime \prime}-\mathrm{H}\right), 7.67$ (ddd, $J=$ 8.5, 7.1, $\left.1.7 \mathrm{~Hz}, 1 \mathrm{H}, 7^{\prime}-\mathrm{H}\right), 8.20$ (dd, $\left.J=8.0,1.7 \mathrm{~Hz}, 1 \mathrm{H}, 5^{\prime}-\mathrm{H}\right) \mathrm{ppm}$. ${ }^{13} \mathrm{C}$ NMR $\left(75 \mathrm{MHz}, \mathrm{CDCl}_{3}\right): \delta=25.8\left(\mathrm{NCH}_{3}\right), 41.1(\mathrm{C}-7 \mathrm{a}), 43.7(\mathrm{C}-3 \mathrm{a})$, $55.4\left(\mathrm{OCH}_{3}\right), 108.8\left(\mathrm{C}-3^{\prime}\right), 113.9\left(\mathrm{C}-3^{\prime \prime}, 5^{\prime \prime}\right), 117.8\left(\mathrm{C}-8^{\prime}\right), 119.9(\mathrm{C}-5)$, 121.5 (C-7), 124.1 (C-4'a), 125.1 (C-6'), 125.7 (C-5'), 127.9 (C-6), 128.1 $\left(\mathrm{C}-2^{\prime \prime}, 6^{\prime \prime}\right), 129.7\left(\mathrm{C}-1^{\prime \prime}\right), 133.8\left(\mathrm{C}-7^{\prime}\right), 136.4(\mathrm{C}-4), 156.0$ (C-8'a), 160.5 (C-4"), 161.8 (C-2'), 175.1, 175.3 (C-1 and C-3), 178.3 (C-4') ppm. ElMS: $m / z(\%)=414(24)[M+H]^{+}, 413(100)[M]^{+*}$. El-HRMS: calcd. for $\mathrm{C}_{25} \mathrm{H}_{19} \mathrm{NO}_{5}[\mathrm{M}]^{+}$413.1263; found 413.1261.

Diisopropyl [(1Z,3Z)-1-(4-Methoxyphenyl)-4-(4-oxo-4Hchromen-2-yl)buta-1,3-diene-1,4-diyl]dicarbamate (15b): DDQ ( $56.3 \mathrm{mg}, 0.248 \mathrm{mmol}$ ) was added to a solution of cycloadduct $\mathbf{1 0 b}$ (63 mg, $0.124 \mathrm{mmol})$ in 1,2,4-TCB $(0.5 \mathrm{~mL})$. The mixture was heated at $165{ }^{\circ} \mathrm{C}$ under MV irradiation (monomode apparatus) for $25 \mathrm{~min}$. The residue was treated with a sodium hydrogen carbonate aqueous solution $(10 \mathrm{~mL})$, and the aqueous layer was extracted with dichloromethane $(3 \times 15 \mathrm{~mL})$. The organic layer was dried with anhydrous sodium sulfate, and the solvent was evaporated to dryness. The residue was purified by preparative TLC with hexane followed by dichloromethane/ethyl acetate (10:1) as the eluent. Yield $8.8 \mathrm{mg}$ (17\%), yellow oil. ${ }^{1} \mathrm{H}$ NMR $\left(500 \mathrm{MHz},\left[\mathrm{D}_{6}\right] \mathrm{DMSO}, 75^{\circ} \mathrm{C}\right): \delta=0.82$, $0.94,1.20,1.25\left[4 \times \mathrm{d}, J=6.2 \mathrm{~Hz}, 3 \mathrm{H}, \mathrm{CO}_{2} \mathrm{CH}\left(\mathrm{CH}_{3}\right)_{2}\right], 3.78(\mathrm{~s}, 3 \mathrm{H}$, $\left.\mathrm{OCH}_{3}\right), 4.60,4.84\left[2 \times \mathrm{sept}, J=6.2 \mathrm{~Hz}, 1 \mathrm{H}, \mathrm{CO}_{2} \mathrm{CH}\left(\mathrm{CH}_{3}\right)_{2}\right], 6.05(\mathrm{~d}$, $J=5.9 \mathrm{~Hz}, 1 \mathrm{H}, 2-\mathrm{H}), 6.07(\mathrm{~s}, 1 \mathrm{H}, 1-\mathrm{NH}), 6.26(\mathrm{~d}, J=5.9 \mathrm{~Hz}, 1 \mathrm{H}, 3-$ $\mathrm{H}), 6.47\left(\mathrm{~s}, 1 \mathrm{H}, 3^{\prime}-\mathrm{H}\right), 6.95\left(\mathrm{~d}, J=8.9 \mathrm{~Hz}, 2 \mathrm{H}, 3^{\prime \prime}, 5^{\prime \prime}-\mathrm{H}\right), 7.48-7.51$ (m, $\left.2 \mathrm{H}, 6^{\prime}-\mathrm{H}, 8^{\prime}-\mathrm{H}\right), 7.54$ (d, J = 8.9 Hz, $\left.2 \mathrm{H}, 2^{\prime \prime}, 6^{\prime \prime}-\mathrm{H}\right), 7.83$ (ddd, $J=$ 8.7, 7.1, $1.7 \mathrm{~Hz}, 1 \mathrm{H}, 7^{\prime}-\mathrm{H}$ ), 7.88 (br s, $1 \mathrm{H}, 4-\mathrm{NH}$ ), 8.04 (dd, J = 7.9, $\left.1.7 \mathrm{~Hz}, 1 \mathrm{H}, 8^{\prime}-\mathrm{H}\right) \mathrm{ppm} .{ }^{13} \mathrm{C}$ NMR $\left(125 \mathrm{MHz},\left[\mathrm{D}_{6}\right] \mathrm{DMSO}, 75^{\circ} \mathrm{C}\right): \delta=$ 20.7, 20.9, 21.4, $21.5\left[1,4-\mathrm{NHCO}_{2} \mathrm{CH}\left(\mathrm{CH}_{3}\right)_{2}\right], 54.9\left(\mathrm{OCH}_{3}\right), 67.75,67.80$ $\left[1,4-\mathrm{NHCO}_{2} \mathrm{CH}\left(\mathrm{CH}_{3}\right)_{2}\right], 79.7(\mathrm{C}-4), 94.3(\mathrm{C}-1), 108.8\left(\mathrm{C}-3^{\prime}\right), 112.5$ $\left(\mathrm{C}-3^{\prime \prime}, 5^{\prime \prime}\right), 117.6\left(\mathrm{C}-8^{\prime}\right), 122.8$ (C-4'a), $124.5\left(\mathrm{C}-5^{\prime}\right), 125.3\left(\mathrm{C}-6^{\prime}\right), 127.3$ $\left(\mathrm{C}-2^{\prime \prime}, 6^{\prime \prime}\right), 127.6(\mathrm{C}-3), 133.1\left(\mathrm{C}-1^{\prime \prime}\right), 134.2\left(\mathrm{C}-7^{\prime}\right), 136.7$ (C-2), 150.5, $154.5\left[1,4-\mathrm{NHCO}_{2} \mathrm{CH}\left(\mathrm{CH}_{3}\right)_{2}\right], 155.2$ (C-8'a), $158.5\left(\mathrm{C}-4^{\prime \prime}\right), 163.7\left(\mathrm{C}-2^{\prime}\right)$, 176.6 (C-4') ppm. El-MS: $m / z(\%)=504$ [M] $^{+\cdot}(34), 418$ (68), 377 (84), 358 (93), 332 (100). El-HRMS: calcd. for $\mathrm{C}_{28} \mathrm{H}_{28} \mathrm{~N}_{2} \mathrm{O}_{7}[\mathrm{M}]^{+}$504.1897; found 504.1898 .

Computational Details: All quantum chemical calculations were performed with the Gaussian 09 software package. ${ }^{[2]}$ The optimized geometries and respective electronic energies were computed at the M06-2X/6-31+G(d,p) level of theory. ${ }^{[25]}$ The structures found were confirmed to correspond to true minima by frequency calculations at the same level of theory, and no imaginary frequencies were found. For some cases, the enthalpies at $T=298 \mathrm{~K}, H_{298 \mathrm{~K}}$, were calculated by considering the contributions of $E_{\mathrm{el}}$, zero-point energy (ZPE), and thermal enthalpy to $T=298.15 \mathrm{~K}$; no scaling factors were used (this is a reasonable approximation for relative comparisons of molecular energetics). The energies of the HOMOs and LUMOs for the optimized geometries of various dienes and dienophiles were computed at the M06-2X/6-31+G(d,p) (within the KS-MO formalism) and MP2/6-31+G(d,p) levels (Hartree-Fock MOs). The HOMO/LUMO energy gap between the diene and dienophile was calculated as $E_{\text {LUMO }}$ (dienophile) $-E_{\text {HOMO }}$ (diene); $E_{\text {LUMO }}$ and $E_{\text {HOMO }}$ are the calculated energies of the respective molecular orbitals. All calculations were performed without symmetry restrictions.

\section{Acknowledgments}

Thanks are due to University of Aveiro and FCT/Ministério da Educação e Ciência (MEC) for the financial support of the QOPNA research unit (FCT UID/QUI/00062/2013) and CIQ-UP (Pest-C/QUI/UI0081/2013) through national funds and, where applicable, cofinanced by the FEDER, within the PT2020 Partnership Agreement, and to the Portuguese NMR Network, as well as to the Instituto Politécnico de Bragança. H. M. T. A. and C. F. R. A. C. L. are grateful to FCT for their PhD (SFRH/BD/ 86277/2012) and Postdoctoral (SFRH/BPD/77972/2011) grants, respectively.

Keywords: Cycloaddition - Oxygen heterocycles · Microwave chemistry · Lewis acids

[1] a) W. Huang, M.-Z. Liu, Y. Li, Y. Tan, G.-F. Yang, Bioorg. Med. Chem. 2007, 15, 5191-5197; b) K. Kanagalakshmi, M. Premanathan, R. Priyanka, B. Hemalatha, A. Vanangamudi, Eur. J. Med. Chem. 2010, 45, 2447-2452.

[2] F. M. Awadallah, T. A. El-Waei, M. M. Hanna, S. E. Abbas, M. Ceruso, B. E. Oz, O. O. Guler, C. T. Supuran, Eur. J. Med. Chem. 2015, 96, 425-435.

[3] a) M. M. Dias, N. F. Machado, M. P. Marques, Food Funct. 2011, 2, 595602 ; b) A. Gomes, O. Neuwirth, M. Freitas, D. Couto, D. Ribeiro, A. G. P. R. Figueiredo, A. M. S. Silva, R. S. G. R. Seixas, D. C. G. A. Pinto, A. C. Tomé, J. A. S. Cavaleiro, E. Fernandes, J. L. F. C. Lima, Bioorg. Med. Chem. 2009, 17, 7218-7226; c) P. Yadav, B. Parshad, P. Manchanda, S. K. Sharma, Curr. Top. Med. Chem. 2014, 14, 2552-2575.

[4] a) A. Gomes, E. Fernandes, A. M. S. Silva, D. C. G. A. Pinto, C. M. M. Santos, J. A. S. Cavaleiro, J. L. F. C. Lima, Biochem. Pharmacol. 2009, 78, 171-177; b) Shaveta, A. Singh, M. Kaur, S. Sharma, R. Bhatti, P. Singh, Eur. J. Med. Chem. 2014, 77, 185-192.

[5] O. Prakash, R. Kumar, V. Parkash, Eur. J. Med. Chem. 2008, 43, 435-440.

[6] M. A. Ibrahim, T. E. Ali, Y. A. Alnamer, Y. A. Gabr, ARKIVOC (Gainesville, FL, U.S.) 2010, 98-135.

[7] R. A. A. Foster, M. C. Willis, Chem. Soc. Rev. 2013, 42, 63-76.

[8] A. Schönberg, A. Mustafa, G. Aziz, J. Am. Chem. Soc. 1954, 76, 45764577.

[9] A. Mustafa, M. I. Ali, J. Org. Chem. 1956, 21, 849-851.

[10] R. M. Letcher, T.-Y. Yue, J. Chem. Res. Synop. 1992, 248.

[11] A. S. Kelkar, R. M. Letcher, K.-K. Cheung, K.-F. Chiu, G. D. Brown, J. Chem. Soc. Perkin Trans. 1 2000, 3732-3741.

[12] H. M. T. Albuquerque, C. M. M. Santos, J. A. S. Cavaleiro, A. M. S. Silva, Eur. J. Org. Chem. 2015, 4732-4743.

[13] a) H. R. El-Seedi, M. A. El-Barbary, D. M. El-Ghorab, L. Bohlin, A. K. BorgKarlson, U. Goransson, R. Verpoorte, Curr. Med. Chem. 2010, 17, 854-901; b) J. A. Manthey, K. Grohmann, N. Guthrie, Curr. Med. Chem. 2001, 8, 135-153.

[14] a) Shagufta, I. Ahmad, Eur. J. Med. Chem. 2016, 116, 267-280; b) M. Dai, X. Yuan, J. Kang, Z.-J. Zhu, R.-C. Yue, H. Yuan, B.-Y. Chen, W.-D. Zhang, R.H. Liu, Q.-Y. Sun, Eur. J. Med. Chem. 2013, 69, 159-166; c) C. Proença, H. M. T. Albuquerque, D. Ribeiro, M. Freitas, C. M. M. Santos, A. M. S. Silva, E. Fernandes, Eur. J. Med. Chem. 2016, 115, 381-392.

[15] M. Singh, M. Kaur, O. Silakari, Eur. J. Med. Chem. 2014, 84, 206-239.

[16] K. Nepali, S. Sharma, M. Sharma, P. M. S. Bedi, K. L. Dhar, Eur. J. Med. Chem. 2014, 77, 422-487.

[17] P.-L. Zhao, W.-F. Ma, A.-N. Duan, M. Zou, Y.-C. Yan, W.-W. You, S.-G. Wu, Eur. J. Med. Chem. 2012, 54, 813-822.

[18] a) N. Guzior, M. Bajda, J. Rakoczy, B. Brus, S. Gobec, B. Malawska, Bioorg. Med. Chem. 2015, 23, 1629-1637; b) N. Guzior, M. Bajda, M. Skrok, K. Kurpiewska, K. Lewiński, B. Brus, A. Pišlar, J. Kos, S. Gobec, B. Malawska, Eur. J. Med. Chem. 2015, 92, 738-749.

[19] C. I. C. Esteves, C. M. M. Santos, C. M. Brito, A. M. S. Silva, J. A. S. Cavaleiro, Synlett 2011, 1403-1406.

[20] G. Battistuzzi, S. Cacchi, G. Fabrizi, Org. Lett. 2003, 5, 777-780.

[21] a) M. A. Murcko, H. Castejon, K. B. Wiberg, J. Phys. Chem. 1996, 100, 16162-16168; b) W. A. Herrebout, B. J. van der Veken, A. Wang, J. R. Durig, J. Phys. Chem. 1995, 99, 578-585.

[22] D. W. Borhani, F. D. Greene, J. Org. Chem. 1986, 51, 1563-1570

[23] a) D. Walker, J. D. Hiebert, Chem. Rev. 1967, 67, 153-195; b) A. E. Wendlandt, S. S. Stahl, Angew. Chem. Int. Ed. 2015, 54, 14638-14658; Angew. Chem. 2015, 127, 14848.

[24] M. Frisch, G. Trucks, H. B. Schlegel, G. Scuseria, M. Robb, J. Cheeseman, G. Scalmani, V. Barone, B. Mennucci, G. Petersson, H. Nakatsuji, M. Cari- 
cato, X. Li, H. P. Hratchian, A. F. Izmaylov, J. Bloino, G. Zheng, J. L. Sonnenberg, M. Hada, M. Ehara, K. Toyota, R. Fukuda, J. Hasegawa, M. Ishida, T. Nakajima, Y. Honda, O. Kitao, H. Nakai, T. Vreven, J. A. Montgomery, Jr., J. E. Peralta, F. Ogliaro, M. Bearpark, J. J. Heyd, E. Brothers, K. N. Kudin, V. N. Staroverov, R. Kobayashi, J. Normand, K. Raghavachari, A. Rendell, J. C. Burant, S. S. Iyengar, J. Tomasi, M. Cossi, N. Rega, J. M. Millam, M. Klene, J. E. Knox, J. B. Cross, V. Bakken, C. Adamo, J. Jaramillo, R. Gomperts, R. E. Stratmann, O. Yazyev, A. J. Austin, R. Cammi, C. Pomelli, J. W. Ochterski,
R. L. Martin, K. Morokuma, V. G. Zakrzewski, G. A. Voth, P. Salvador, J. J. Dannenberg, S. Dapprich, A. D. Daniels, Ö. Farkas, J. B. Foresman, J. V. Ortiz, J. Cioslowski, D. J. Fox, Gaussian 09, Gaussian, Inc., Wallingford, CT, 2009, 19, p. 227-238.

[25] Y. Zhao, D. G. Truhlar, Theor. Chem. Acc. 2008, 120, 215-241.

Received: August 31, 2016

Published Online: November 25, 2016 